\title{
TINGKAT KEPUASAN PETANI PADI PANDANWANGI TERHADAP KINERJA PENYULUH LAPANGAN DI DESA BABAKANKARET KECAMATAN CIANJUR KABUPATEN CIANJUR
}

\author{
Oleh : \\ Asep Saepul Alam*) \\ Mugi Velayati**)
}

\begin{abstract}
Abstrak
Cianjur merupakan salah satu daerah penghasil paadi yang telah terdaftar sebagai pemilik Sertifikasi Indikasi Geografis yaitu padi Pandanwangi yang memeiliki aroma yang khas dan hanya mampu dibudidayakan di 7 kecamatan di Kabupaten Cianjur. Dalam budidaya padi Pandanwangi petani tidak lepas dari peran penyuluh lapangan. Untuk itu tujuan penelitian yaitu: (1) Untuk mengetahui atribut pelayanan lapangan terhadap petani di Desa Babakankaret Kecamatan Cianjur Kabupaten Cianjur,dan (2) Untuk mengetahui tingkat kepuasan petani terhadap penyuluh lapangan di Desa Babakankaret Kecamatan Cianjur Kabupaten Cianjur. Penelitian ini menggunakan data primer dan sekunder dimana data Primer diperoleh dari wawancara dan pengisian kusioner kepada responden dan data Sekunder merupakan data yang diperoleh dari Studi pustaka, Internet dan literatur instansi atau dinas terkait. Metode analisis yang digunakan adalah CSI (Customer Satisfaction Index) dan IPA (Importance Performance Analysis). Hasil Analisis CSI terhadap Atribut pelayanan adalah sebesar $74,03 \%$. Nilai tersebut berada pada rentang $60-80 \%$ yang menunjukan petani merasa puas terhadap atribut pelayanan penyuluh lapang. Hasil IPA menunjukan atribut yang dianggap sangat penting berdasarkan kepentingan dan kinerja yaitu pentinganya penyuluh lapang memperhatikan penampilan dan kerapihan saat dilapang dan pada atribut pentingnya penyuluh lapangan menyampaikan informasi teknologi baru kepada petani. Sedangkan atribut yang memiliki tingkat kinerja paling tinggi yaitu penampilan dan kerapihan penyuluh dan tingkat kinerja peling rendah yaitu pada kemampuan penyuluh menggunakan bahasa setempat.
\end{abstract}

Kata kunci: Kepusan, kinerja, penyuluh, padi Pandanwangi.

\begin{abstract}
Cianjur is one of the rice producing areas that has been registered as the owner of the Georaphical Indication Certification, namely Pandanwangi rice which has a distinctive arome and can only be cultivated in 7 sub-districts in Cianjur Regency. In Pandanwangi rice cultivation, farmers cannit be separated from the role of field counselors. For this purpose, the research objectives are: (1) to determine the attributes of field service to farmers in Babakankaret Village, Cianjur. And (2) to determine the level of farmer satisfaction with the extension agents in Babakankaret Village, Cianjur. This study uses Primary and Secondary data where Primary data is obtained from interviews and questionnaires to respondent and Secondary data is data obtained from literature studies, the internet and related agency or agency literature. The analytical method used is CSI (Customer Satisfaction Index) and IPA (Importance Performabce Analysis). CSI anaalysis results for the service attribute is $74,03 \%$. This value is in the range of 60-80\% which shows that farmers
\end{abstract}

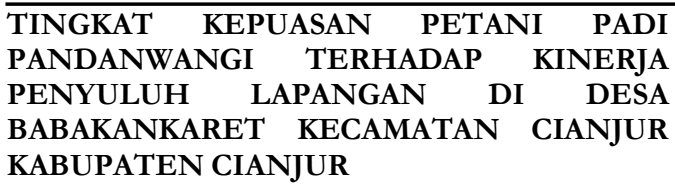


are satisfied with the servicw extension field service. The results of the Natiral Sciences show attributes that are considered to be very important based on interests and performance, namely the importance of the field instructor paying attention to appearance and tidiness when fielded and on the attributes op importance the field instructor conveying new tenological information to farmers. While the attributes that have the highest level of performance are the appearance and neatness of the instructor and the lowest level of performance is the ability of the instructor to use the local language.

Keyword: Satisfaction, performance, extension agent, Pandanwangi rice.

*) Dosen Fakultas Sains Terapan UNSUR

**) Alumni Fakultas Sains Terapan UNSUR 


\section{PENDAHULUAN}

Pertanian merupakan salah satu sektor utama yang menopang kehidupan masyarakat karena sebagai mata pencaharian bagi sebagian besar penduduk Indonesia. Berdasarkan data BPS 2014 mengatakan bahwa penduduk yang bekerja di sektor pertanian berjumlah sekitar 38.973 .033 orang atau $40 \%$ dari total penduduk usia produktif. Sedangkan sisanya sebanyak $60 \%$ tersebar diberbagai sektor diluar pertanian. Oleh karena itu, pertanian dapat dikatakan sebagai salah satu penopang perekonomian nasional yang artinya bahwa sektor pertanian memegang peran penting dan seharusnya menjadi penggerak dari kegiatan perekonomian.

Dalam mewujudkan pertanian sebagai salah satu kegiatan unggulan ekonomi nasional perlu adanya dibuatkan sistem pertanian berkelanjutan yang efesien, berbasis IPTEK dan sumberdaya lokal, dan berwawasan lingkungan melalui pendekatan sistem agribisnis. Sistem agribisnis merupakan sebagai konsep dari suatu sistem yang integratif yang terdiri dari beberapa subsistem, yaitu (1) subsistem pengadaan sarana produksi pertanian diantara pembibitan, agrokimia, agro-otomotif dan agromekanik; (2) subsistem produksi usaha tani yang kegiatan ekonominya menggunakan sarana produksi usahatani untuk menghasilkan produk pertanian primer; (3) subsistem pengolahan dan industri hasil pertanian yaitu kegiatan industri yang berfungsi mengolah produk pertanian primer menjadi bahan olahan produk; (4) subsistem pemasaran dan (5) subsistem kelembagaan penunjang yaitu sebagai kegiatan yang menyediakan jasa bagi agribisnis seperti pendidikan, penyuluhan, infrastruktur, perbankan, litbang, transportasi dan lain-lain. Pandangan sistem tersebut menyatakan bahwa kinerja masing-masing kegiatan dalam sistem agribisnis sangat ditentukan oleh subsistem lainnya yang saling memiliki keterkaitan antara satu sama lain.
Subsistem lembaga panjang berupa kegiatan penyuluhan merupakan salah satu subsistem yang cukup besar agar dapat memberikan kontribusi pada keberhasilan pertanian khususnya tanaman padi di Indonesia karena sebagai proses bimbingan dan pendidikan nonformal bagi petani. Kegiatan penyuluhan ini sangat penting yang bertujuan untuk meningkatkan aspek kognitif (pengetahuan), efektif (sikap mental), dan prikomotorik (keterampilan). Penyuluhan pertanian tidak hanya memberikan sebuah proses penyampaian informasi saja, tetapi dapat menajdi wadah sarana konsultasi, pelatihan, dan aktivitas lain yang dapat mengubah prilaku para petani agar lebih handal dan sejahtera. selain daripada itu, bahwa pada tahun 1984 dan tahun 2007 indonesia telah memberikan prestasi terbaiknya adalah dibidang pengimpor beras terbesar di dunia menjadi Negara swasembada beras. oleh karena itu, penyluhan pertanian sangat pentingkarena memberikan sumbangan yang sangat signifikan dalam pencapaian berbagai program pembangunan pertanian.

Kabupaten Cianjur merupakan salah satu sentra produksi padi di Provinsi Jawa Barat yang memiliki potensi luas lahan sawah yang cukup besar dengan hasil produksi yang tinggi. Di Kabupaten Cianjur sekitar $96 \%$ produksi padi dipasok dari lahan wasah irigasi dan sawah tadah hujan dengan menggunakan varietas unggul sedangkan lahan kering yang tersebar disemua kecamatan belum banyak kontribusinya dalam peningkatan produksi padi (Amatu As Saheda, 2008).

Salah satu padi unggulan Kabupaten Cianjur adalah padi Pandanwangi. Padi Pandanwangi mempunyai keunggulan dari segi aroma, rasa, tekstur dan harga jual yang cukup tinggi dibandingkan dengan beras lainnya.

Pada saat ini penyuluh pertanian memiliki peran yang strategis terutama dalam gerakan revitalisasi pertanian karena sebagai jembatan komunikasi antara pemerintah dengan petani. 
Sehingga petani akan mengadopsi berbagai teknologi terbaru dan bergantung pada pendampingan yang dilakukan penyuluh. Begitu pula dengan berbagai program pembangunan pertanian yuang digagas pemerintah, akan diikuti atau tidak oleh petani bergantung sejauh mana keterlibatan para penyuluh.

Menurut Suparta (2001) menyatakan bahwa penyuluhan merupakam jasa layanan dan informasi agribisnis yang dilakukan melalui proses pendidikan non formal untuk petani dan pihak-pihak terkait yang memerlukan agar kemampuannya berkembang secara dinamis sehingga jasa layanan penyuluhan yang dibuat harus bermutu agar dapat memenuhi kebutuhan dan harapan sasaran penyuluhan pada waktu yang diperlukan. Mutu jasa layanan dapat dilihat dari segi keandalan (reliability), kepastian (assurance), penampilan (tangible), empati (empathy), dan ketanggapan (responsiveness). Selain daripada itu, jasa layanan dilakukan melalui proses pendidikan non formal pun guna sebagai meningkatkan kesadaran para pelaku sistem agribisnis (sasaran), yang dapat disampaikan secara langsung maupun tidak langsung melalui berbagai media cetak atau elektronik. Dengan demikian, sasaran penyuluhan diharapkan dapat meningkat kemampuannya secara dinamis dengan menyelesaikan setiap permasalahan yang dihadapinya secara mandiri, berpikir kreatif, inovatif, berani, dan bebas mengambil keputusan dalam memecahkan segala persoalan bahkan memberikan kekuatan dan kemampuan pada prospek pengembangan usahanya ke depan untuk lebih maju serta mampu bersaing dengan yang lainya.

Penyuluh harus memiliki komunikasi dua arah yaitu mampu menyampaikan (berbicara dan menulis) dan mampu menerima (mendengar dan membaca). Oleh karena itu, kualifikasi seorang penyuluh sangat penting untuk diperhatikan. Karena tersedianya penyuluh di suatu desa tidak menjamin dapat memberikan hasil yang sama, itu tergantung bagaimana penyuluh dapat memberikan kepuasan terhadap petani dengan kinerja yang dihasilkan.

Kepuasan merupakan perasaan senang atau kecewa yang muncul setelah membandingkan antara pelayanan yang dipikirkan terhadap hasil yang diharapkan. Maka dari itu diperlukan penelitian untuk mengetahui seberapa besar tingkat kepuasan petani terhadap kinerja penyuluh lapangan.

Tujuan dari penelitian ini adalah sebagai berikut :

1. Untuk mengetahui atribut pelayanan penyuluh lapangan terhadap petani Padi Pandanwangi di Desa Babakankaret Kecamatan Cianjur Kabupaten Cianjur

2. Untuk mengetahui tingkat kepuasan petani Padi Pandanwangi terhadap Kinerja penyuluh lapangan di Desa Babakankaret Kecamatan Cianjur Kabupaten Cianjur

\section{METODE PENELITIAN}

\section{Tempat dan Waktu}

Penelitian dilaksanakan di Desa Babakankaret Kecamatan Cianjur Kabupaten Cianjur. Karena di Desa ini merupakan salah satu sentra penanaman padi Pandanwangi dan terdapat penyuluh lapangan yang melakukan kegiatan lapangan secara berkelanjutan maka saya sebagai peneliti tertarik untuk melakukan penelitian mengenai tingkat kepuasan petani padi Pandanwangi terhadap kinerja penyuluh lapangan di desa tersebut. Penelitian ini dilakukan dari bulan Mei sampai dengan Agustus 2019.

\section{Jenis Data}

Penelitian ini menggunakan data primer dan sekunder. Data primer merupakan data yang didapat dari sumber pertama baik dari individu atau perseorangan. Dalam penelitian ini data yang diperoleh secara langsung berasal dari hasil wawancara langsung dengan narasumber selaku Penyuluh Lapangan di Desa Babakankaret Kecamatan Cianjur 
Kabupaten Cianjur dan melalui pengisian kuisioner oleh responden (petani).

Sedangkan data sekunder, yaitu data yang diperoleh dari instansi seperti pemerintah atau lembaga terkait dengan berbagai literatur-literatur yang dapat menunjang penelitian. Alasan peneliti melakukan penelitian terhadap petani padi Pandanwangi selain pandanwangi adalah beras lokal yang menjadi khas di daerah Cianjur juga keberhasilan seorang petani tidak lepas dari peran seorang penyuluh lapangan dalam melakukan tugasnya, salah satu cara untuk melihat tercapai atau tidaknya sukses atau tidaknya penyuluh dalam melakukan tugas lapangan dapat dilihat dari tingkat kepuasan itu sendiri, oleh karena itu peneliti tertarik meneliti Tingkat Kepuasan Petani Pandanwangi Terhadap Kinerja Penyuluh Lapangan di Desa Babakankaret Kecamatan Cianjur Kabupaten Cianjur yang merupakan salah satu sentra penanaman padi pandanwangi.

\section{Teknik Pengumpulan Data}

Teknik pengumpulan data yang digunakan dalam penelitian yang diakukan di Desa Babakankaret Kecamatan Cianjur Kabupaten Cianjur adalah:

\section{Wawancara}

Wawancara merupakan proses kegiatan tanyajawab dua orang atau lebih guna mendapatkan informasi yang dibutuhkan untuk penelitian, diantaranya ada seorang pewawancara dan responden. Dan menurut Sugiono (2008) menyatakan bahwa wawancara merupakan proses memperoleh kegiatan untuk tujuan penelitian dengan cara tanya jawab, sambil bertatap muka diantara penannya atau pewawancara dengan responden serta mengutamakan alat yang dinamakan panduan.

\section{Observasi}

Ritongga (2016) Penulis melakukan pengamatan langsung kelapangan untuk mendapatkan data yang penulis butuhkan. Observasi yaitu teknik pengumpulan data yang dilakukan secara sistematis melalui pengamatan. Pelaksanaan observasi dilakukan karena untuk mengetahui kondisi awal tempat penelitian, untuk mengetahui program pelatihan yang dilaksanakan, dari mulai perencanaan, pelaksanaan, evaluasi dan laporan.

\section{Kuisioner}

Kuisioner menurut Sugiyono (2009) menyatakan bahwa kuisioner merupakan teknik pengumpulan data yang dilakukan dengan member seperangkat pertanyaan tertulis kepada responden untuk dijawabnya. Kuisioner merupakan teknik pengumpulan data yang efisien bila peneliti tahu dengan variable yang akan diukur dan tahu apa yang bias diharapkan dari responden cukup besar dan tersebar di wilayah yang luas. Kuisioner dapat berupa pertanyaan tertutup dan biasa pertanyaan terbuka yang diberikan langsung kepada responden.

\section{Dokumentasi}

Dokumentasi menurut Sugiyono (2015) adalah suatu cara yang digunakan untuk memperoleh data dan informasi dalam bentuk buku, arsip, dokumen, tulisan angka dan gambar yang berupa laporan serta keterangan yang dapat mendukung penelitian. Dokumentasi digunakan untuk mengumpulkan data kemudian ditelaah.

\section{Populasi}

Populasi adalah wilayah generalisasi yang terdiri dari suatu objek atau subjek yang mempunyai kualitas serta karakteristik tertentu yang telah ditetapkan oleh peneliti yang hendak diteliti dan ditarik sebuah kesimpulan Sugiyono dalam Nuryana (2018). Populasi dalam penelitian ini adalah semua petani padi Pandanwangi yang ada di Desa Babakankaret Kecamatan Cianjur Kabupaten Cianjur yang berjumlah 34 orang. Seluruh populasi dijadikan sebagai sampel penelitian (sensus), sehinggga sampel berjumlah 34 orang.

\section{Variabel Penelitian}

Menurut Sugiono dalam Nuryana (2018) varibel penelitian merupakan suatu atribut atau sifat yang dijadikan nilai dari orang, objek ataupun kegiatan yang 
mempunyai variasi tertentu yang ditetapkan oleh peneliti untuk dipelajari dan dapat ditarik sebuah kesimpulannya. Dalam penelitian ini yang menjadi variabel bebas X adalah Tangible, Reliability, Responsiveness, Assurance dan Empathy.
Sedangkan untuk variabel terikat $\mathrm{Y}$ adalah Kepuasan Petani. Dalam penelitian ini peneliti mengoperasionalkan variabel penelitian saperti pada tabel 1. sebagai berikut:

Tabel 1. Operasional Variabel.

\begin{tabular}{|c|c|}
\hline $\begin{array}{l}\text { Variabel } \\
\text { penelitian }\end{array}$ & Konsep Variabel \\
\hline Tangible & $\begin{array}{l}\text { Menurut Zoeldhan (2012) pelayanan } \\
\text { bukti fisik biasanya berupa pelayanan } \\
\text { yang digunakan, performance } \\
\text { pemberi pelayanan yang dapat sesuai } \\
\text { dengan karakteristik pelayanan yang } \\
\text { diberikan dalam menunjukkan } \\
\text { prestasi kerja yang bisa diberikan } \\
\text { dalam bentuk pelayanan fisik yang } \\
\text { dapat dilihat. }\end{array}$ \\
\hline Reliability & $\begin{array}{l}\text { Menurut Zoeldhan (2012) } \\
\text { kehandalan merupakan suatu bentuk } \\
\text { ciri khas atau suatu karakteristik dari } \\
\text { pegawai yang memiliki prestasi kerja } \\
\text { tinggi. }\end{array}$ \\
\hline & $\begin{array}{l}\text { Menurut Tjiptono (2007) yaitu } \\
\text { keinginan para staf da karyawan } \\
\text { untuk bisa membantu para pelanggan } \\
\text { dan memberikan sebuah pelayanan } \\
\text { dengan tanggap. }\end{array}$ \\
\hline
\end{tabular}

1. Praktek langsung dilapangan

2. Pemberian informasi teknologi baru

3. Memberikan informasi pasar

Ordinal

4. Pengupayaan sarana dan prasarana

1. Cepat tanggap dalam menghadapi masalah yang timbul

2. Mengajarkan usaha tani, melakukan bimbingan serta Ordinal melakukan penerapannya

3. Petugas merekap atau menanyakan masalah kepada petani dan mencari solusi

\begin{tabular}{|c|c|c|c|}
\hline Assurance & $\begin{array}{l}\text { Menurut Salim (2007) asuransi adalah } \\
\text { suatu kemauan untuk menetapkan } \\
\text { kerugian-kerugian kecil (sedikit) yang } \\
\text { sudah pasti sebagai pengganti atau } \\
\text { subtitusi kerugian-kerugian besar } \\
\text { yang belum terjadi. }\end{array}$ & $\begin{array}{l}\text { 1. Keramahan } \\
\text { 2. Pelayanan atau penyelesaian } \\
\text { masalah secara tuntas } \\
\text { 3. Pengetahuan masalah di } \\
\text { lapangan }\end{array}$ & Ordinal \\
\hline Empathy & $\begin{array}{l}\text { Menurut Nursodik (2012) empati } \\
\text { adalah perhatian secara individual } \\
\text { yang bisa diberikan perusahaan } \\
\text { kepada pelanggan seperti kemudahan } \\
\text { dalam menghubungi sebuah } \\
\text { perusahaan, kemampuan karayawan } \\
\text { untuk berkomunikasi dengan } \\
\text { pelanggan, dan } \\
\text { pelanggannya. }\end{array}$ & $\begin{array}{l}\text { 1. Mudah ditemui atau } \\
\text { dihubungi } \\
\text { 2. Pelayanan yang sama kepada } \\
\text { petani }\end{array}$ & Ordinal \\
\hline $\begin{array}{l}\text { Kepuasan } \\
\text { Konsumen }\end{array}$ & $\begin{array}{l}\text { Menurut Bachtiar (2011) kepuasan } \\
\text { konsumen merupakan suatu perasaan } \\
\text { positif konsumen yang berhubungan } \\
\text { dengan produk atau jasa selama } \\
\text { menggunakan atau } \\
\text { menggunakan. }\end{array}$ & & Ordinal \\
\hline
\end{tabular}

Sumber: (Sugiono, Metode Penelitian Kuantitatif Kualitatif dan R\&D, 2015).

\begin{tabular}{llr}
\hline TINGKAT KEPUASAN PETANI & PADI \\
PANDANWANGI TERHADAP & KINERJA \\
PENYULUH LAPANGAN DI & DESA \\
BABAKANKARET KECAMATAN & CIANJUR \\
KABUPATEN CIANJUR &
\end{tabular}




\section{Analisis Deskriptip}

Menurut Sugiono (2015), analisis deskriptif merupakan statistik yang digunakan untuk menganalisa data dengan cara menggambarkan atau mendeskripsikan data yang telah terkumpul sebagaimana adanya tanpa ada maksud membuat sebuah kesimpulan yang berlaku untuk umum atau generalisasi. Statistik deskriptif dapat digunakan untuk mendeskriptifkan sampel.

\section{Analisis Kuantitatif}

Analisis kuantitatif merupakan pengukuran data kuantitatif dan statistik objektif melelui perhitungan ilmiah yang berasal atau didapat dari sampel orangorang yang telah ditentukan yaitu 34 orang yang diminta untuk menjawab atas sejumlah pertanyaan tentang survei untuk menentukan frekuensi dan persentase tanggapan responden.

1. Analisis Imfortance and Performance
Analysis (IPA)
Menurut Ruhimat (2008), metode Importance Performance Analysis (IPA) merupakan suatu teknik penerapan yang mudah untuk mengatur atribut dari tingkat kepentingan dan tingkat pelaksanaan itu sendiri yang berguna untuk pengembangan program pemasaran yang efektif.

Menurut Magal dan Levenburg dalam Subagio (2010) bahwa metode Importance Performance Analysis pertama kali diperkenalkan oleh Martila dan James pada tahun 1977 dengan tujuan untuk mengukur hubungan antara persepsi konsumen dan prioritas peningkatan kualitas produk/jasa yang dikenal pula sebagai quadrant analysis. Importance Performance Analysis telah diterima secara umum dan dipergunakan pada berbagai bidang kajian karena kemudahan untuk diterapkan dan tampilan hasil analisa yang memudahkan usulan perbaikan kinerja. Importance Performance Analysis mempunyai fungsi utama untuk menampilkan informasi berkaitan dengan faktor-faktor pelayanan yang menurut konsumen sangat mempengaruhi kepuasan dan loyalitas mereka, dan faktor-faktor pelayanan yang menurut konsumen perlu ditingkatkan karena kondisi saat ini belum memuaskan. Dalam analisis Importance and Performance Analysis (IP A) ini terdapat 21 atribut yang hendak diujikan, maka pengukuran menggunakan skala semantic differentials lima tingkat yang terdiri dari sangat penting, cukup penting, tidak penting dan sangat tidak penting. Penilaian setiap atribut yang akan menjadi bahan pertanyaan adalah sebagai berikut:

1) Jawaban sangat penting dibeli nilai 5

2) Jawaban penting diberi nilai 4

3) Jawaban cukup penting diberi nilai 3

4) Jawaban tidak penting diberi nilai 2

5) Jawaban sangat tidak penting diberi nilai 1

Untuk rentang skala pada tingkat

kepentingan adalah sebagai berikut:

1) -1.79 sangat tidak penting

2) $1.80-2.59$ tidak penting

3) $2.60-3.39$ cukup penting

4) $3.40-4.19$ penting

5) 4.20 - 5.00 sangat penting

Untuk rentang skala pada tingkat kinerja adalah sebagai berikut:

1) - 1.79 sangat tidak puas

2) $1.80-2.59$ tidak puas

3) $2.60-3.39$ cukup puas

4) $3.40-4.19$ puas

5) $4.20-5.00$ sangat puas

Dalam penelitian terdapat dua variabel yang diwakilkan dalam huruf $\mathrm{X}$ dan Y. X merupakan tingkat kinerja dari Penyuluh Lapangan yang dapat memberikan suatu kepuasan kepada para petani Pandanwangi, sedangkan $\mathrm{Y}$ merupakan tingkat kepuasan dari petani Pandanwangi terhadap kinerja Penyuluh Lapangan. Selanjutnya sumbu mendatar (X) akan diisi oleh skor rata-rata tingkat kinerja, sedangkan sumbu tegak $(\mathrm{Y})$ akan diisi oleh skor rata-rata tingkat kepuasan dengan rumus berikut :

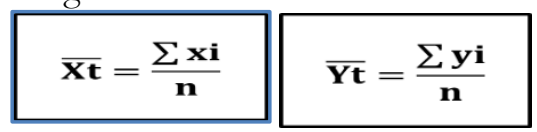

Sumber : Magal Simha R, Levenburg Nancy M. 2005. Using Importance Performance Analysis. 
Keterangan:

$\mathrm{Xt}=$ Nilai rata-rata tingkat kinerja atribut ke-i

$\mathrm{Yt}=$ Nilai rata-rata tingkat kepentingan atribut ke-i

$\mathrm{Xi}=$ Total skor tingkat kinerja atribut kei

Yi $=$ Total skor tingkat kepentingan atribut ke-i

$\mathrm{n}=$ Jumlah data konsumen

Diagram kartesius merupakan suatu bagan yang dibagi menjadi 4 (empat) daerah dan dibatasi oleh 2 (dua) batas garis yang berpotongan tegak lurus pada titik-titik $(X, Y)$. Nilai X dan Y digunakan sebagai pasangan koordinat titik atribut yang memposisikan suatu atribut terletak pada diagram kartesius. Titik tersebut dapat diperoleh dari rumus sebagai berikut:

$\overline{\mathbf{X}}=\frac{\sum \boldsymbol{X}}{\boldsymbol{K}} \quad \overline{\mathbf{Y}}=\frac{\sum \boldsymbol{Y}}{\boldsymbol{K}}$

Sumber : Magal Simha R, Levenburg Nancy M. 2005. Using Importance Performance Analysis.

Keterangan:

$\mathrm{X}=$ Skor rata-rata dari rata-rata tingkat kinerja seluruh atribut

$\mathrm{Y}=$ Skor rata-rata dari rata-rata tingkat kepentingan seluruh atribut

$\mathrm{k}=$ Banyaknya atribut yang diteliti Selanjutnya akan tergambarkan dalam 4 kuadran.

2. Analisis Customer Satisfaction Index (CSI)

Customer Satisfatin Index atau Indeks Kepuasan Konsumen merupakan sebuah metode yang menggunakan indeks untuk mengukur tingkat kepuasan konsumen secara menyeluruh terhadap kinerja penyuluh menurut Stratford dalam Nuryana (2018), pengukuran indeks ini dilakukan dengan 4 (empat) tahapan yaitu:

a) Menemukan Means Important Score (MIS) dan Means Satisfaction Score (MSS), nilai ini diperoleh berdasarkan nilai rata-rata tingkat kepentingan dan nilai rata-rata kinerja tiap responden.

MIS $=\frac{\sum_{i=1}^{n} Y i}{n} \quad$ MSS $=\frac{\sum_{i=1}^{n} X i}{n}$

Sumber : Magal Simha R, Levenburg Nancy M. 2005. Using Importance Performance Analysis.

Keterangan:

$\mathrm{N}=$ Jumlah responden

$Y i=$ Nilai kepentingan atribut ke-i

$\mathrm{Xi}=$ Nilai kinerja atribut ke- $\mathrm{i}$

b) Membuat Weight Factor (WF), bobot ini merupakan persentase nilai MIS tiap atribut terhadap nilai MIS seluruh atribut. Rumusnya adalah sebagai berikut :

$\frac{\text { WFi }=\text { MISi }}{\sum_{\mathbf{i}=1} \text { MISi }}$

Sumber : Magal Simha R, Levenburg Nancy M. 2005. Using Importance Performance Analysis.

Keterangan:

$\mathrm{P}=$ Jumlah aribut kepentingan

$\mathrm{I}=$ Atribut ke-i

c) Membuat Weight Score (WS), bobot ini merupakan perkalian antara Weight Factor (WF) dan Means Satisfaction Score (MSS) atau rata-rata tingkat kepuasan, rumusnya adalah sebagai berikut:

\section{$\mathrm{WS}_{1}=\mathrm{WF}_{1} \cdot \mathrm{MSS}_{1}$}

Sumber : Magal Simha R, Levenburg Nancy M. 2005. Using Importance Performance Analysis.

Total Weight Score (WS) atribut ke-1 (a-1) hingga atribut terakhir (a-p) disebut dengan Weight Average Total (WAT).

d) Menentukan nilai CSI

$\operatorname{CSI}=\frac{\sum_{i=1}^{p} \text { WSI } \times 100 \%}{H S}$

Sumber : Magal Simha R, Levenburg Nancy M. 2005. Using Importance Performance Analysis.

Keterangan:

$\mathrm{P}=$ nilai ke $\mathrm{p}$

$\mathrm{HS}=$ Skala maksimum yang digunakan. 
e) Kriteria indeks kepuasan menggunakan kisaean 0 hingga $100 \%$ (tidak puas hingga sangat puas), yaitu kepuasan tertinggi dicapai bila nilai CSI menunjukan 100\%. Berdasarkan Simamora (2002) dalam Fathiyakan (2017), untuk membuat skala linier numeric diawali dengan mencari rentang skala (RS) dengan rumus sebagai berikut:

$$
\mathbf{R S}=\frac{(\mathbf{m}-\mathbf{n})}{\mathbf{b}}
$$

Sumber : Magal Simha R, Levenburg Nancy M. 2005. Using Importance Performance Analysis.

Keterangan:

RS = Rentang skala

Tabel 2. Kriteria Nilai Customer Satisfaction Index.

\begin{tabular}{ll}
\hline \multicolumn{1}{c}{ Nilai CSI } & \multicolumn{1}{c}{ Kriteria CSI } \\
\hline $0 \%<$ CSI $\leq 20 \%$ & Sangat tidak puas \\
$20 \%<$ CSI $\leq 40 \%$ & Tidak puas \\
$40 \%<$ CSI $\leq 60 \%$ & Cukup puas \\
$60 \%<$ CSI $\leq 80 \%$ & Puas \\
$80 \%<$ CSI $\leq 100 \%$ & Sangat puas \\
\hline
\end{tabular}

Sumber: Data sekunder, Subagio (2010).

\section{HASIL DAN PEMBAHASAN}

\section{Gambaran Umum Wilayah Desa Babakankaret Cianjur}

\section{Letak Geografis}

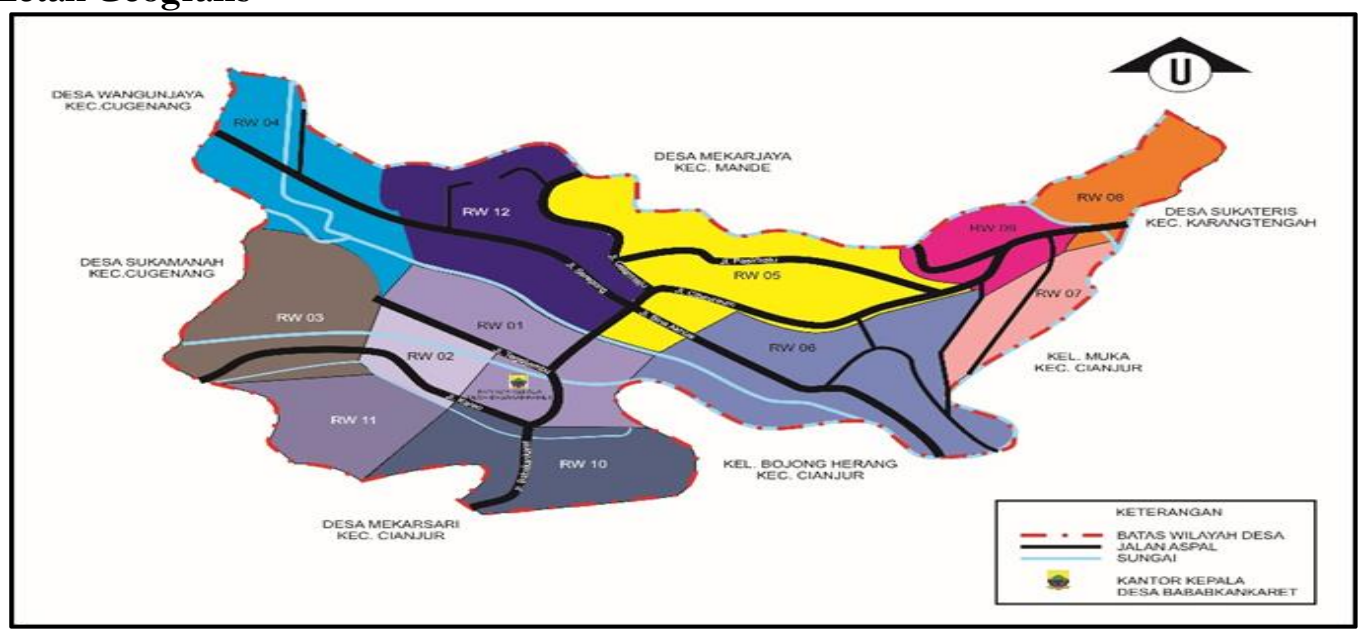

Gambar 1. Peta Wilayah Desa Babakankaret Kecamatan Cianjur Kabupaten Cianjur. Sumber: Data Sekunder, profil Desa Babakankaret (2019).

Desa Babakankaret memiliki kedudukan yang cukup strategis selain berada di kecamatan kota juga berbatasan dengan 2 desa dalam kecamatan cianjur dan 2 desa luar kecamatan Cianjur,

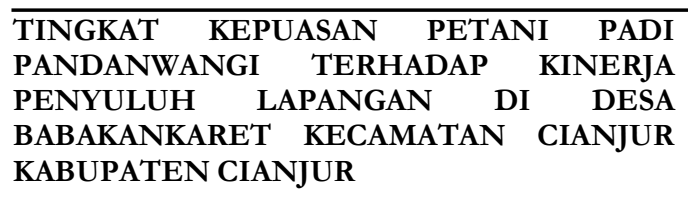


perbatasan antara tersebut yaitu sebagai berikut :

a) Sebelah Utara berbatasan dengan Desa Mekarjaya Kecamatan Mande.

b) Sebelah Selatan berbatasan dangan Desa Mekarsari Kecamatan Cianjur.

c) Sebelah Timur berbatasan dangan Desa Sukataris Kecamatan Karangtengah.

d) Sebelah Barat berbatasan dangan Desa Sukamanah Kecamatan Cugenang

Tabel 3. Penggunaan dan Luas lahan.

\begin{tabular}{ccc}
\hline No & Penggunaan & Luas lahan \\
\hline 1 & Perumahan pemukiman & 30,850 ha \\
2 & Sawah & 199,170 ha \\
3 & Perkantoran/Sekolah & 5,000 ha \\
4 & Tanah kas Desa & 21,430 ha \\
5 & Makam/Kuburan & 61,170 ha \\
6 & Kolam/Empang & 7,8710 ha \\
7 & Jalan & 8,800 ha \\
8 & Lapangan olahraga & 38,000 ha \\
9 & Lain-lain & 37,230 ha \\
\hline
\end{tabular}

Sumber: Data Sekunder, profil Desa Babakankaret (2019). berikut:

Selain itu Desa Babakankaret ini juga terdiri dari 12 Rukun Warga yaitu sebagai

Tabel 4. Rukun Warga Desa Babakankaret Kecamatan Cianjur.

\begin{tabular}{ccc}
\hline No & Rukun Warga & Nama Ketua Rukun Warga \\
\hline 1 & 01 & Bekti Alimin Nur \\
2 & 02 & Komarti \\
3 & 03 & Uuh Wiharja \\
4 & 04 & Udan \\
5 & 05 & Yayat Hidayat \\
6 & 06 & Cece Makmur \\
7 & 07 & Asep Wawan \\
8 & 08 & Idham Abdul Karim \\
9 & 09 & Asep Mulyana \\
10 & 10 & Dede Suparman \\
11 & 11 & A Latif \\
12 & 12 & Dadang Aos \\
\hline
\end{tabular}

Sumber: Data Sekunder, profil Desa Babakankaret (2019).

\section{Kondisi Demografis}

Dari aspek sosial ekonomi jumlah angkatan kerja sebanyak 2654 jiwa dengan jumlah angkatan kerja bekerja penuh sebanyak 1.156 jiwa dan angkatan kerja bekerja tidak penuh sebanyak 14.98
Luas wilayah Desa Babakankaret $\pm 500,270$ ha dengan letak geografis desa babakankaret berada di $-6,808453$ Lintang Selatan dan 107.133884 Bujur Timur dengan ketinggian rata-rata 416 diatas permukaan laut.

Jangkauan (orbitasi) jarak tempuh dari desa Babakankaret ke Kantor Kecamatan Cianjur adalah $2 \mathrm{Km}$ dan ke Kantor Kabupaten adalah 2 KM. Adapun Luas Lahan dan Penggunaannya sebagai berikut: 
Tabel 5. Profesi Desa Babakan karet Kecamatan Cianjur.

\begin{tabular}{|c|c|c|}
\hline No & Pekerjaan & Jumlah \\
\hline 1 & Ibu Rumah Tangga & 552 \\
\hline 2 & PNS & 58 \\
\hline 3 & TNI/POLRI & 8 \\
\hline 4 & Pedagang & 24 \\
\hline 5 & Pensiunan & 15 \\
\hline 6 & Karyawan swasta & 77 \\
\hline 7 & Bidang jasa & 5 \\
\hline 8 & Buruh perusahaan/Pabrik & 55 \\
\hline 9 & Petani/Buruh tani & 88 \\
\hline 10 & Peternakan & 5 \\
\hline 11 & Pengrajin & 3 \\
\hline 12 & Buruh serabutan & 350 \\
\hline 13 & Lain-lain & 11 \\
\hline
\end{tabular}

Sumber: Data Sekunder, profil Desa Babakankaret (2019).

\section{Sarana Pendidikan}

Sarana pendidikan di Desa Babakankaret Kecamatan Cianjur Kabupaten Cianjur dapat dilihat pada table 6. sudah terpenuhi sebagian sarana pendidikan, namun terdapat kendala pada jarak tempuh sekolah karena angkutan umum yang jarang menuju desa ini. Di bawah ini terdapat tabel mengenai jumlah sarana pendidikan di Desa babakankaret Kecamatan Cianjur Kabupaten Cianjur :

Tabel 6. Sarana Pendidikan di Desa Babakankaret Kecamatan Cianjur.

\begin{tabular}{|c|c|c|}
\hline No & Jenis Pendidikan & Banyaknya \\
\hline 1 & PAUD/RA TPA & 12 \\
\hline 2 & $\mathrm{SD} / \mathrm{MI}$ & 4 \\
\hline 3 & SLTP/MTS & 3 \\
\hline 4 & SLTA/SMK/MA & 1 \\
\hline 5 & Paket A & - \\
\hline 6 & Paket B & - \\
\hline 7 & Paket C & - \\
\hline 8 & Pengajian Dewasa Putra/i & 20 \\
\hline 9 & Pengajiam Anak & 43 \\
\hline 10 & Pengajian Remaja & 20 \\
\hline 11 & Kelompok Belajar & 1 \\
\hline 12 & Pesantren & 2 \\
\hline 13 & TPA/Diniyah & 9 \\
\hline 14 & Perguruan Tinggi & - \\
\hline & Jumlah & 114 \\
\hline
\end{tabular}

Sumber: Data Sekunder, profil Desa Babakankaret (2019).

\section{Sarana Kesehatan}

Adapun terdapat beberapa sarana kesehatan yang berada di Desa
Babakankaret Kecamatan Cianjur Kabupaten Cianjur dapat dilihat pada table 7 . diantaranya sebagai berikut: 
Tabel 7. Sarana kesehatan di Desa Babakankaret Kecamatan Cianjur.

\begin{tabular}{clc}
\hline No & \multicolumn{1}{c}{ Sarana kesehatan } & Jumlah \\
\hline 1 & Rumah Sakit & - \\
2 & Puskesmas & - \\
3 & Puskesmas pembantu & 1 Buah \\
4 & Poskesdesa & 1 Buah \\
5 & Rumah bersalin & 1 Buah \\
6 & Pos KB Desa & 1 Pos \\
7 & Posyandu & 11 Buah \\
8 & Pengobatan alternatif & 1 Buah \\
9 & Pustu & 1 Buah \\
\hline
\end{tabular}

Sumber: Data Sekunder, profil Desa Babakankaret (2019).

\section{Karakteristik Responden}

Pengambilan data dari 34 responden ini menggunakan kuisioner yang diberikan secara langsung dengan teknik wawancara pada saat pengisian kuisioner, 34 responden ini merupakan petani padi di Desa Babakankaret Kabupaten Cianjur. Karakteristik responden yang telah ditetapkan oleh peneliti yaitu sebagai berikut: Jenis Kelamin, usia, pendidikan dan pengalaman bertani padi.
1. Jenis Kelamin

Berdasarkan gambar 4.2 dapat dilihat jumlah responden yang berada di Desa Babakankaret Kecamatan Cianjur Kabupaten Cianjur lebih dominan yang berjenis kelamin laki-laki dan ada beberapa yang berjenis kelamin perempuan sebagai responden. Dari jumlah 34 responden ada 76\% laki-laki dan $24 \%$ adalah perempuan. Jadi dapat disimpulkan bahwa sebagian petani di Desa Babakankaret ini adalah laki-laki.

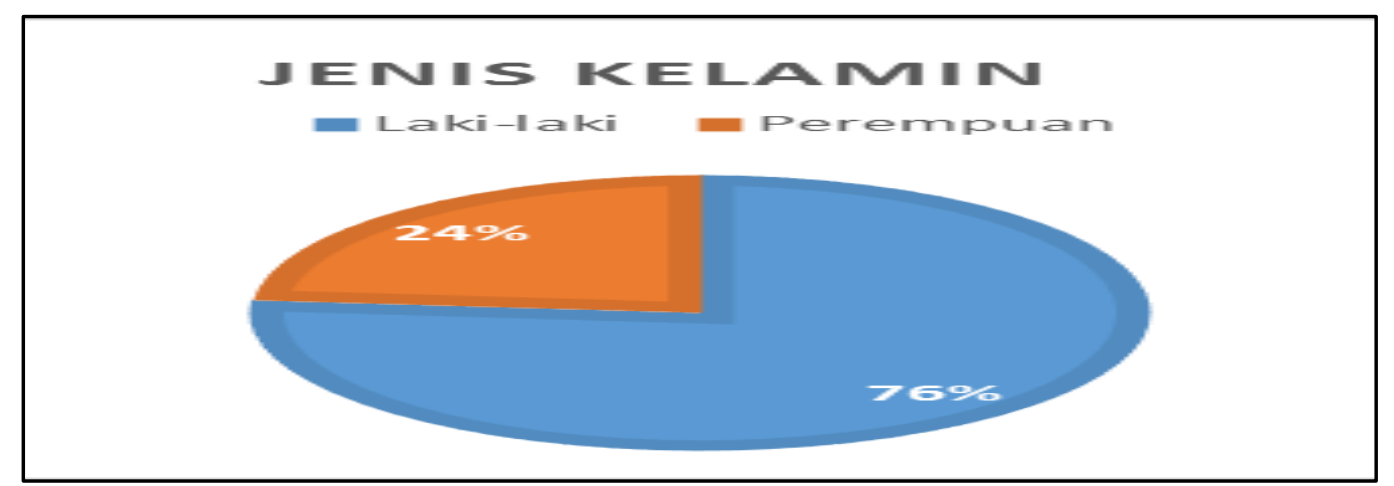

Gambar 2. Jenis Kelamin Responden (2019).

\section{Usia}

berdasarkan hasil wawancara kepada 34 responden dapat dilihat pada gambar di bawah. Gambar di bawah menunjukan bahwa usia responden ratarata $>50$ tahun, dengan usia di atas 50 tahun ini dapat dikatakan bahwa responden sudah sangat berpengalaman dalam bertani. Dengan jumlah 34 responden, $>50$ tahun sebanyak 59\% (20 orang), $=50$ tahun sebanyak $6 \%$ (5 orang) dan sisanya yaitu $<50$ tahun sebanyak $35 \%$ (12 orang). 


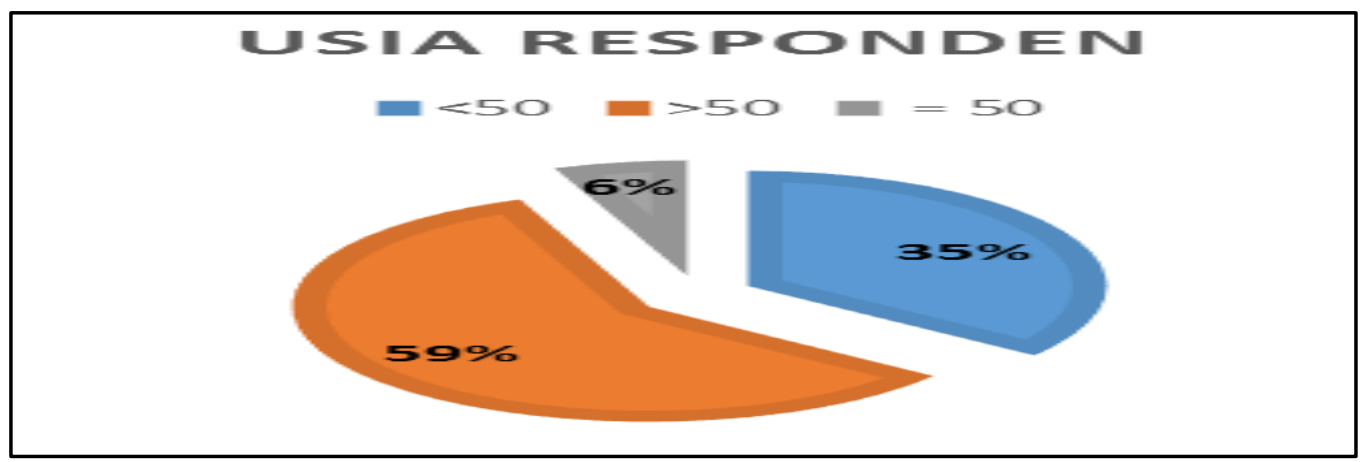

Gambar 3. Usia responden (2019).

3. Pendidikan

Karakteristik responden berdasarkan pendidikan. Berdasarkan hasil wawancara hampir semua responden dengan pendidikan terakhir di Sekolah Dasar (SD) bahkan ada beberapa responden yang hanya pernah bersekolah (tidak lulus SD), responden yang pernah bersekolah ini malah lebih banyak dibandingankan dengan responden yang terakhir berpendidikan di Sekolah Menengah Pertama (SMP). Bisa dilihat pada gambar di bawah hanya 3\% (1 orang) responden yang memiliki tingakat pendidikan di SMP dan 15\% (5 orang) yang pernah bersekolah (tidak lulus SD) kemudian selebihnya 82\% (28 orang).

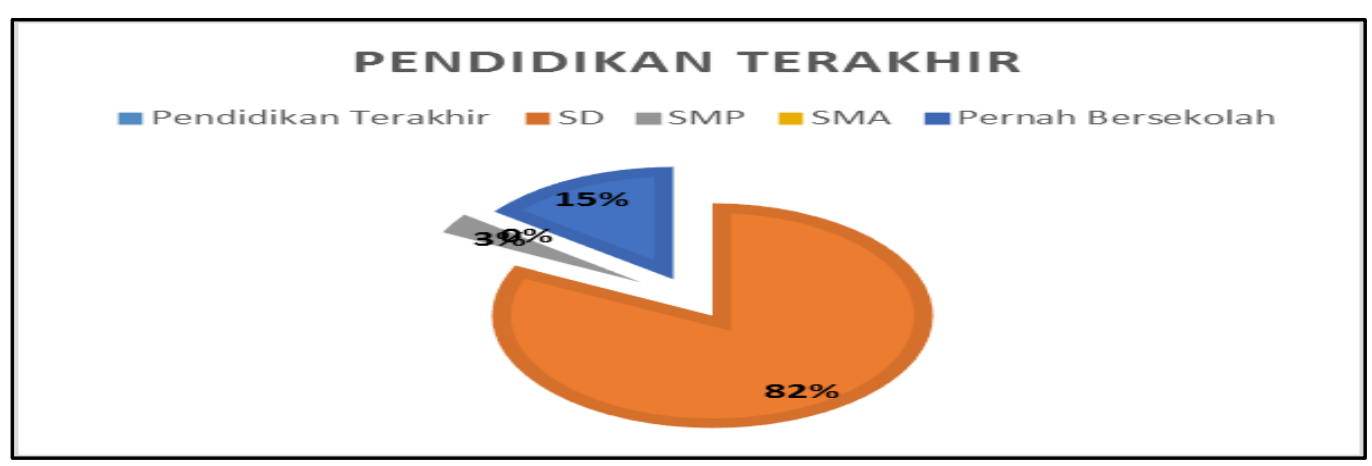

Gambar 4. Pendidikan terakhir responden (2019).

4. Pengalaman Bertani Padi

Karakteristik responden berdasarkan pengalaman bertani, berdasarkan gambar di bawah menunjukan bahwa banyak petani yang memiliki pengalaman yang sudah cukup lama dan dapat dilihat sebanyak 62\% (21 orang) responden yang sudah bertani selama 10 tahun, 2 tahun sebanyak 21\% (7 orang), 5 tahun sebanyak 14\% (5 orang), 7 tahun $3 \%$ (1 orang) dan selebihnya tidak ada pengalaman selama kurun waktu 1, 3, 4, 6, 8, dan 9 tahun.

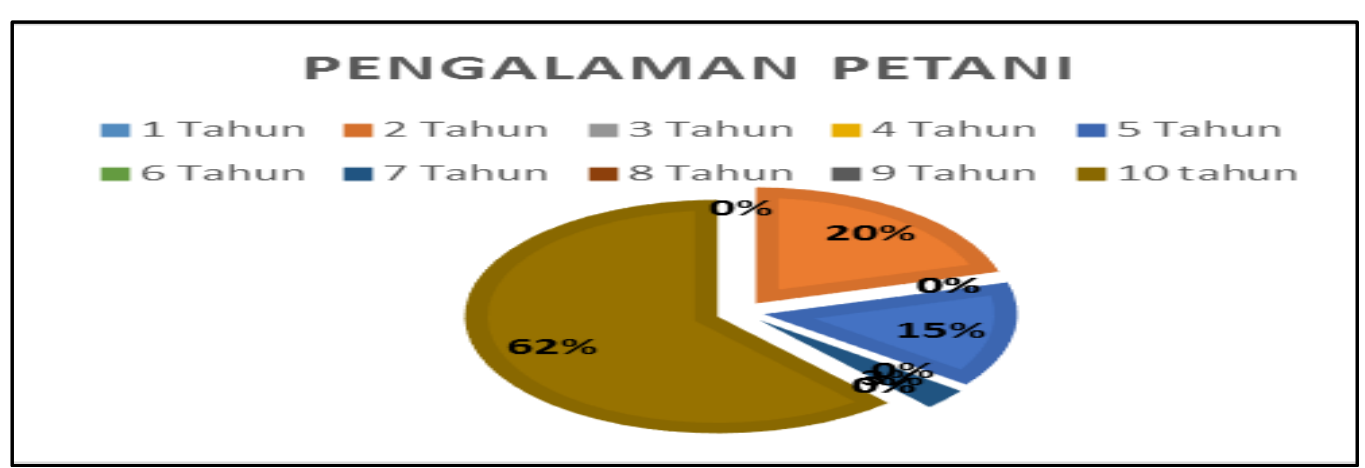

Gambar 2. Pengalaman bertani responden (2019).

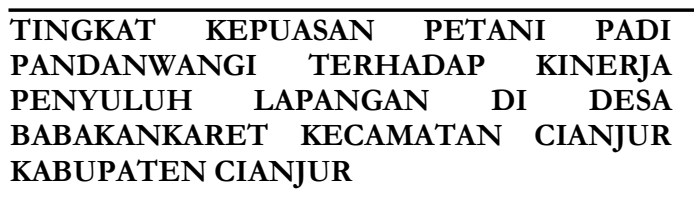

TINGKAT KEPUASAN PETANI PADI

PENYULUH LAPANGAN DI DESA

KABUPATEN CIANJUR 
Penilaian Tingkat Kepentingan dan Tingkat Kepuasan menurut Atribut atribut Kualitas Pelayanan

Mutu pelayanan yang diberikan penyuluh lapangan BPP Cianjur akan sangat berpengaruh terhadap pelayanan yang diberikan oleh penyuluh lapangannya. Kepuasan petani dipengaruhi oleh pelayanan yang diberikan oleh penyuluh lapangan. Dengan adanya penilaian yang diberikan oleh petani terhadap penyuluh lapangan harapan petani yaitu dapat mengimbangi dengan kinerja penyuluh lapangan Desa Babakankaret Kecamatan Cianjur Kabupaten Cianjur.

Adapun atribut - atribut yang digunakan untuk menilai tingkat kepentingan dan kinerja terhadap penyuluh lapangan di BPP Cianjur bisa dilihat pada tabel 8. sebagai berikut:

Tabel 8. Atribut - atribut Penilaian tingkat kepentingan dan kinerja terhadap penyuluh lapangan di Desa Babakankaret Cianjur.

\begin{tabular}{clc}
\hline Dimensi & \multicolumn{1}{c}{ Atribut - Atribut Pelayanan } & \\
\hline \multirow{2}{*}{ Tangible } & 1. Kerapihan dan penampilan penyuluh & A1 \\
& 2. Kemampuan penyuluh dalam melaksanakan bahasa setempat & A2 \\
& 1. Praktek langsung di lapangan & A3 \\
& 2. Pelatihan dan kunjungan secara teratur oleh penyuluh & A4 \\
& 3. Pengupayanan sarana dan prasarana & A5 \\
Reability & 4. Penyusunan rencana kegiatan usaha tani & A6 \\
& 5. Membantu administrasi kelompok & A7 \\
& 6. Memberikan informasi teknologi baru & A8 \\
& 7. Memberikan informasi pasar & A9 \\
& 8. Memberikan informasi peluang usaha dan permodalan & A10 \\
& 9. Peningkatan hasil usaha & A11 \\
Responsiveness & 1. Cepat tanggap dalam menghadapi masalah yang timbul & A12 \\
& 2. Kecepatan menangani pengaduan petani & A13 \\
& 1. Membantu dalam pengambilan keputusan guna menjalin kemitraan & A14 \\
& \multicolumn{1}{c}{ usaha } & A15 \\
Assurance & 2. Keramahan & A16 \\
& 3. Pengetahuan dan kecakapan dalam memberikan materi & A17 \\
& 4. Pelayanan / menyelesaikan masalah secara tuntas & A18 \\
& 5. Pengetahuan permasalahan di lapangan & A19 \\
& 1. Mudah ditemui atau dihubungi & A20
\end{tabular}

Adapun penjabaran untuk masing masing atribut adalah sebagai berikut :

1. Dimensi Tangible (penampilan)

1) Kerapihan dan penampilan penyuluh

Kerapihan dan penampilan penyuluh merupakan atirbut yang dapat dilihat langsung oleh petani dan termasuk salah satu atribut yang sering dinilai langsung oleh petani ketika.

2) Kemampuan penyululuh lapang menggunakan bahasa setempat

Kemampuan penyuluh dalam mengunakan basaha setempat juga sesuatu yang penting dan dapat dilihat secara langsung oleh petani, karena dengan begitu berarti penyuluh lapang dalam setiap pelayanannya memperhatikan lingkungan tida hanya sekedar memberikan informasi dan pengarahan saja.

\section{Dimensi Reliability (keandalan)}

1) Praktek langsung dilapangan

Praktek langsung di lapangan merupakan hal yang penting untuk mempraktekan langsung materi yang disuluhkan seperti teknis cara penanaman, pemupukan, pemberia pakan untuk ternak serta bagaimana penangan hasil usaha pertanian. 
2) Pelatihan dan kunjungan secara teratur oleh petani

Pertemuan yang rutin antara penyuluh dengan petani dilakukan untuk mendiskusikan permasalahan yang timbul dan melihat perkembangan petani.

3) Pengupayaan sarana dan prasarana Pengupayaan sarana dan prasarana ini sangat diinginkan oleh petani untuk kegiatan usaha baik dalam bentuk bantuan langsung, seperti pengadaan traktor, obat obatan, bibit, dan lain-lain.

4) Penyusunan rencana kegiatan usaha tani

Rencana kegiatan usaha tani sangat diperlukan oleh petani untuk mengetahui perkiraan biaya dan hasil usaha yang akan didapat.

5) Membantu administrasi kelompok Kelompok tani diwajibkan membuat kelengkapan administrasi kelompoknya seperti Rencana Defentif Kebutuhan Kelompok (RDKK), Rencana Usaha Kelompok (RUK), berita acara pembentukan dan sebagainnya.

6) Memberikan informasi teknologi baru

Memberikan informasi yang luas kepada para petani mengenai teknologi baru yang penting dilakukan guna meningkatkan hasil taninya. Teknologi tersebut dapat berupa informasi benih unggul, cara penanaman, pemupukan, pemberian pakan serta pengolahan hasil pertanian.

7) Memberikan informasi pasar

Memebrikan informasi yang luas kepada petani dalam hal informasi pasar dapat membantu petani untuk mempermudah penjualan hasil usahannya. Sebagai penyuluh tetntunya harus dapat memebantu petani mencari pasar yang dapat menguntungkan petani.

8) Memberikan informasi peluang usaha dan permodalan

Memberikan informasi yang luas kepada petani dalam hal pengadaan permodalan dan peluang usaha yang dapat memperlancar peningkatan usaha tani, misalnya informasi kredit usaha tani, kredit sarana kebutuhan petani, dan menampung hasil usaha para petani yang akan memuaskan para petani.

9) Peningkatan hasil usaha

Dengan adanya penyuluhan diharapkan dapat meningkatkan hasil usaha para petani yang akan berdampak pada peningkatan keuntungan serta meningkatkan taraf hidup petani.

\section{Dimensi}

Responsiveness (kesigapan)

1) Cepat tanggap dalam menghadapi masalah yang timbul

Kemampuan penyuluh untuk cepat tanggap dalam mengahdapi masalah yang timbul baik mengenai teknis di lapangan seperti hama atau penyakit maupun masalah yang timbul di kelompok. Penyuluh harus segera dapat mengatasi masalah tersebut agar tidak mempengaruhi hasil usaha aktivitas petani.

2) Kecepatan menangani pengaduan petani

Dalam atribut ini diperlukan suatu kemampuan untuk cepat tanggap dan penyuluh terhadap keluhan atau pengaduan yang disampaikan oleh petani.

\section{Dimensi Assurance (kepastian)}

1) Membantu pengambilan keputusan guna menjalin kemitraan usaha

Penyuluh harus dapat membantu petani dalam masalah pengambilan keputusan tersebut, 
karena hal ini akan menentukan keberhasilan usaha petani.

2) Keramahan penyuluh

Dalam memberikan penyuluhan yang efektif, diharapkan penyuluh bersikap ramah serta siap menolong kepada petani.

3) Pengetahuan dan kecakapan dalam memberikan materi

Atribut ini menuntut penyuluh untuk memiliki pengetahuan mengenai materi yang akan disuluhkannya serta cara berkomunikasi yang baik agar materi yang dibeikan mudah dimengerti oleh petani.

4) Pelayanan dan menyelesaikan masalah secara tuntas

Pelayanan secara tuntas akan membuat petani lebih mengandalkan dan yakin akan keberadaan penyuluh lapangan.

5) Pengetahuan permasalahan di lapangan

Pengetahuan dan kemampuan penyuluh dalam mengatahui permasalahan di lapangan akan sangat membantu petani untuk menyelesaikan masalah mereka, mulai dari maslaah teknis di lapangan ataupun masalah administrasi kelompok tani.

\section{Dimensi Empathy (empati)}

1) Mudah ditemui atau dihubungi

Kemudahan untuk ditemui dan dihubungi untuk berkonsultasi, akan membuat petani merasa nyaman, merasa bahwa penyuluh benra - benar mempperhatikan petani dan benar benar ada untuk petani.

2) Pelayanan yang sama kepada petani Pemberian pelayanan yang sama kepada semua petani dapat menimbulkan kenyamanan bagi petani, sehingga tidak terjadi perbedaan kelas sosial dalam seuatu kelompok tani.

3) Perhatian khusus atas masalah tertentu

Adanya permasalahan tertentu yang dihadapi seorang petani, memerlukan penanganan khusus secra perorang secara langsung kepada individu yang bersangkutan, dengan begitu masalah yang timbul akan mudah diatasi.

\section{Analisis Deskriptif}

Menurut Nuryana (2018) Hasil dari observasi yang dilakukan sebagai dasar dari sebuah penelitian menunjukan sebuah argumen dan pendapat yang berbeda dari setiap responden yang mengetahui dan merasakan peran penyuluh.

Seluruh responden petani mampu menjawab keseluruhan dari pertanyaan yang diajukan dengan jawaban yang bervariasi sesuai dengan yang diharapkan dan dirasakan oleh petani. Hasil kuesioner yang berupa jawaban dan tanggapan atas atribut-atribut pertanyaan yang telah diajukan dapat dilihat pada tabel 9 . sebagai berikut : 
Tabel 9. Penilaian Kepentingan Terhadap Penyuluh.

\begin{tabular}{|c|c|c|c|c|c|c|c|c|c|}
\hline No & $\begin{array}{l}\text { VARIA } \\
\text { BEL }\end{array}$ & Pernyataan & 1 & 2 & 3 & 4 & 5 & $\begin{array}{c}\text { rata- } \\
\text { rata }\end{array}$ & $\begin{array}{c}\text { Kriteri } \\
\text { a }\end{array}$ \\
\hline A1 & \multirow{2}{*}{$\begin{array}{l}\text { TANGI } \\
\text { BLE }\end{array}$} & Kerapihan dari penampilan penyuluh & 0 & 0 & 1 & 24 & 9 & 4,24 & $\begin{array}{l}\text { Sangat } \\
\text { penting }\end{array}$ \\
\hline A2 & & $\begin{array}{l}\text { Kemampuan penyuluh dalam } \\
\text { menggunakan bahasa setempat }\end{array}$ & 0 & 0 & 6 & 21 & 7 & 4,03 & Penting \\
\hline A3 & \multirow{9}{*}{$\begin{array}{l}\text { RELIA } \\
\text { BILITY }\end{array}$} & $\begin{array}{l}\text { Praktek langsung di lapangan pada saat } \\
\text { pelatihan dan kunjungan }\end{array}$ & 0 & 0 & 2 & 26 & 6 & 4,12 & Penting \\
\hline A4 & & $\begin{array}{l}\text { Pentingkah melaksanakan pelatihan dan } \\
\text { kunjungan secara teratur }\end{array}$ & 0 & 0 & 3 & 25 & 6 & 4,09 & Penting \\
\hline A5 & & $\begin{array}{l}\text { Pengupayaan sarana dan prasarana yang } \\
\text { dibutuhkan petani }\end{array}$ & 0 & 0 & 3 & 25 & 6 & 4,09 & Penting \\
\hline A6 & & $\begin{array}{l}\text { Pentingkah penyuluh lapang membantu } \\
\text { petani atau kelompok tani dalam } \\
\text { penyusunan rencna kegiatan usaha tani }\end{array}$ & 0 & 0 & 4 & 25 & 5 & 4,03 & Penting \\
\hline A7 & & $\begin{array}{l}\text { Membantu petani atau kelompok tani } \\
\text { untuk membuat administrasi kelompok } \\
\text { seperti proposal, RDKK, buku } \\
\text { administrasi, laporan bulanan kelompok } \\
\text { dan sebagainya }\end{array}$ & 0 & 0 & 1 & 28 & 5 & 4,12 & Penting \\
\hline A8 & & $\begin{array}{l}\text { Pentingkah penyuluh lapang } \\
\text { menyampaikan informasi teknologi baru }\end{array}$ & 0 & 0 & 1 & 24 & 9 & 4,24 & $\begin{array}{l}\text { Sangat } \\
\text { penting }\end{array}$ \\
\hline A9 & & $\begin{array}{l}\text { Pentingkah penyuluh lapang } \\
\text { menyampaikan informasi pasar }\end{array}$ & 0 & 0 & 0 & 28 & 6 & 4,18 & Penting \\
\hline A10 & & $\begin{array}{l}\text { Pentingkah penyuluh lapang } \\
\text { menyampaikan informasi peluang usaha } \\
\text { dan permodalan }\end{array}$ & 0 & 0 & 0 & 29 & 5 & 4,15 & Penting \\
\hline A11 & & $\begin{array}{l}\text { Pengaruh penyuluh lapang terhadap } \\
\text { peningkatan hasil usaha }\end{array}$ & 0 & 0 & 2 & 30 & 2 & 4,00 & Penting \\
\hline A12 & $\begin{array}{l}\text { RESPO } \\
\text { NSIVE }\end{array}$ & $\begin{array}{l}\text { Kemampuan penyuluh untuk cepat } \\
\text { tanggap dalam menghadapi masalah yang } \\
\text { timbul }\end{array}$ & 0 & 0 & 2 & 27 & 5 & 4,09 & Penting \\
\hline A13 & NESS & $\begin{array}{l}\text { Kecepatan dalam menangani pengaduan } \\
\text { petani }\end{array}$ & 0 & 0 & 3 & 26 & 5 & 4,06 & Penting \\
\hline A14 & \multirow{5}{*}{$\begin{array}{l}\text { ASSUR } \\
\text { ANCE }\end{array}$} & $\begin{array}{l}\text { Memberikan bimbingan dan memecahkan } \\
\text { masalah petani atau kelompok tani dalam } \\
\text { pengambilan keputusan guna menjalin } \\
\text { kemitraan usaha dibidang pertanian }\end{array}$ & 0 & 0 & 4 & 27 & 3 & 3,97 & Penting \\
\hline A15 & & Pentingkah penyuluh berikap ramah & 0 & 0 & 3 & 24 & 7 & 4,12 & Penting \\
\hline A16 & & $\begin{array}{l}\text { Pengetahuan dan kecakapan dalam } \\
\text { memberikan informasi yang jelas dan } \\
\text { mudah dimenegrti kepada petani }\end{array}$ & 0 & 0 & 1 & 29 & 4 & 4,09 & Penting \\
\hline A17 & & $\begin{array}{l}\text { Memberikan pelayanan atau } \\
\text { menyelesaikan masalah secara tuntas }\end{array}$ & 0 & 0 & 2 & 26 & 6 & 4,12 & Penting \\
\hline A18 & & $\begin{array}{l}\text { Pengetahuan dan kemampuan penyuluh } \\
\text { dalam mengetahui permasalahan di } \\
\text { lapangan (penyakit, hama, dll) }\end{array}$ & 0 & 0 & 1 & 25 & 8 & 4,21 & $\begin{array}{l}\text { Sangat } \\
\text { penting }\end{array}$ \\
\hline A19 & \multirow{4}{*}{$\begin{array}{l}E M P A T \\
\quad H Y\end{array}$} & $\begin{array}{l}\text { Mudah ditemui dan dihubungi untuk } \\
\text { berkonsultasi }\end{array}$ & 0 & 0 & 3 & 22 & 9 & 4,18 & Penting \\
\hline A20 & & $\begin{array}{l}\text { Pelayanan yang sama kepada semua petani } \\
\text { tanpa pilih-pilih }\end{array}$ & 0 & 0 & 2 & 25 & 7 & 4,15 & Penting \\
\hline A21 & & $\begin{array}{l}\text { Memberikan perhatian khusus (individual) } \\
\text { atas masalah tertentu (khusus) }\end{array}$ & 0 & 0 & 2 & 27 & 5 & 4,09 & Penting \\
\hline & & Rata-rata keseluruhan & & & & & & 4,11 & Penting \\
\hline
\end{tabular}


Hasil penilaian keseluruhan dari 34 responden yang telah menjawab pertanyaan tentang tingkat kepentingan atas atribut penyuluh yang tercantum dalam kuesioner maka diperoleh rata rata dari setiap pertanyaan dengan nilai masing-masing yang berbeda. Atribut yang di anggap sangat penting dan diharapkan sesuai dengan harapan petani terletak pada variabel tangible dan reliability dan dengan pernyataan pentingnya seorang penyuluh memperhatikan kerapihan dari penampilannya dan pernyataan pentingnya penyuluh lapang menyampaikan informasi teknologi baru kepada petani dengan perolehan rata-rata $(4,24)$ dan kemudian pada variabel assurance dengan pernyataan bahwa pengetahuan dan kemampuan penyuluh dalam mengetahui pemasalahan di lapangan (penyakit, hama, dll) dengan nilai rata-rata $(4,21)$ dimana ke-3 atribut tersebut memiliki nilai rata-rata yang menunjukan sangat penting.

Pada tabel penilaian kepentingan diatas memiliki nilai rata-rata yang dianggap penting oleh semua petani sehingga hanya ada 1 pernyataan yang memiliki nilai rata-rata $(3,97)$ yaitu terletak pada variabel assurance dengan pernyataan pentingnya penyuluh memberikan bimbingan dan memecahkan masalah petani dalam pengambilan keputusan guna menjalin kemitraan usaha dibidang pertanian. Dengan hasil penilaian diatas menghasilkan nilai rata-rata keseluruhan dari tingkat kepentingan sebesar 4,11.

Dimana nilai tersebut menunjukan bahwa tingkat kepentingan berada pada rentan $3.40-4.19$ yang berarti penting oleh petani.

Tabel 10. Penilaian Kinerja Petani Terhadap Penyuluh.

\begin{tabular}{|c|c|c|c|c|c|c|c|c|c|}
\hline No & $\begin{array}{c}\text { VARIA } \\
\text { BEL }\end{array}$ & Pernyataan & 1 & 2 & 3 & 4 & 5 & $\begin{array}{c}\text { rata- } \\
\text { rata }\end{array}$ & $\begin{array}{l}\text { Kriteri } \\
\quad \text { a }\end{array}$ \\
\hline A1 & $T A N G I$ & $\begin{array}{l}\text { Kerapihan dari penampilan } \\
\text { penyuluh. }\end{array}$ & 0 & 0 & 8 & 20 & 6 & 3,94 & Puas \\
\hline $\mathrm{A} 2$ & $B L E$ & $\begin{array}{l}\text { Kemampuan penyuluh dalam } \\
\text { menggunakan bahasa setempat. }\end{array}$ & 0 & 2 & 17 & 15 & 0 & 3,38 & $\begin{array}{l}\text { Cukup } \\
\text { puas }\end{array}$ \\
\hline A3 & & $\begin{array}{l}\text { Praktek langsung di lapangan pada } \\
\text { saat pelatihan dan kunjungan. }\end{array}$ & 0 & 0 & 11 & 22 & 1 & 3,71 & Puas \\
\hline A4 & & $\begin{array}{l}\text { Pentingkah melaksanakan pelatihan } \\
\text { dan kunjungan secara teratur. }\end{array}$ & 0 & 0 & 12 & 22 & 0 & 3,65 & Puas \\
\hline A5 & & $\begin{array}{l}\text { Pengupayaan sarana dan prasarana } \\
\text { yang dibutuhkan petani. }\end{array}$ & 0 & 0 & 10 & 24 & 0 & 3,71 & Puas \\
\hline A6 & & $\begin{array}{l}\text { Pentingkah penyuluh lapang } \\
\text { membantu petani atau kelompok } \\
\text { tani dalam penyusunan rencna } \\
\text { kegiatan usaha tani. }\end{array}$ & 0 & 0 & 10 & 22 & 2 & 3,76 & Puas \\
\hline A7 & $\begin{array}{l}\text { RELIA } \\
\text { BILITY }\end{array}$ & $\begin{array}{l}\text { Membantu petani atau kelompok } \\
\text { tani untuk membuat administrasi } \\
\text { kelompok seperti proposal, } \\
\text { RDKK, buku administrasi, laporan } \\
\text { bulanan kelompok dan sebagainya. }\end{array}$ & 0 & 0 & 12 & 21 & 1 & 3,68 & Puas \\
\hline A8 & & $\begin{array}{l}\text { Pentingkah penyuluh lapang } \\
\text { menyampaikan informasi teknologi } \\
\text { baru. }\end{array}$ & 0 & 0 & 11 & 22 & 1 & 3,71 & Puas \\
\hline A9 & & $\begin{array}{l}\text { Pentingkah penyuluh lapang } \\
\text { menyampaikan informasi pasar. } \\
\text { Pentingkah penyuluh lapang }\end{array}$ & 0 & 0 & 6 & 27 & 1 & 3,85 & Puas \\
\hline A10 & & $\begin{array}{l}\text { menyampaikan informasi peluang } \\
\text { usaha dan permodalan. }\end{array}$ & 0 & 0 & 8 & 26 & 0 & 3,76 & Puas \\
\hline A11 & & $\begin{array}{l}\text { Pengaruh penyuluh lapang } \\
\text { terhadap peningkatan hasil usaha. }\end{array}$ & 0 & 0 & 13 & 21 & 0 & 3,62 & Puas \\
\hline
\end{tabular}




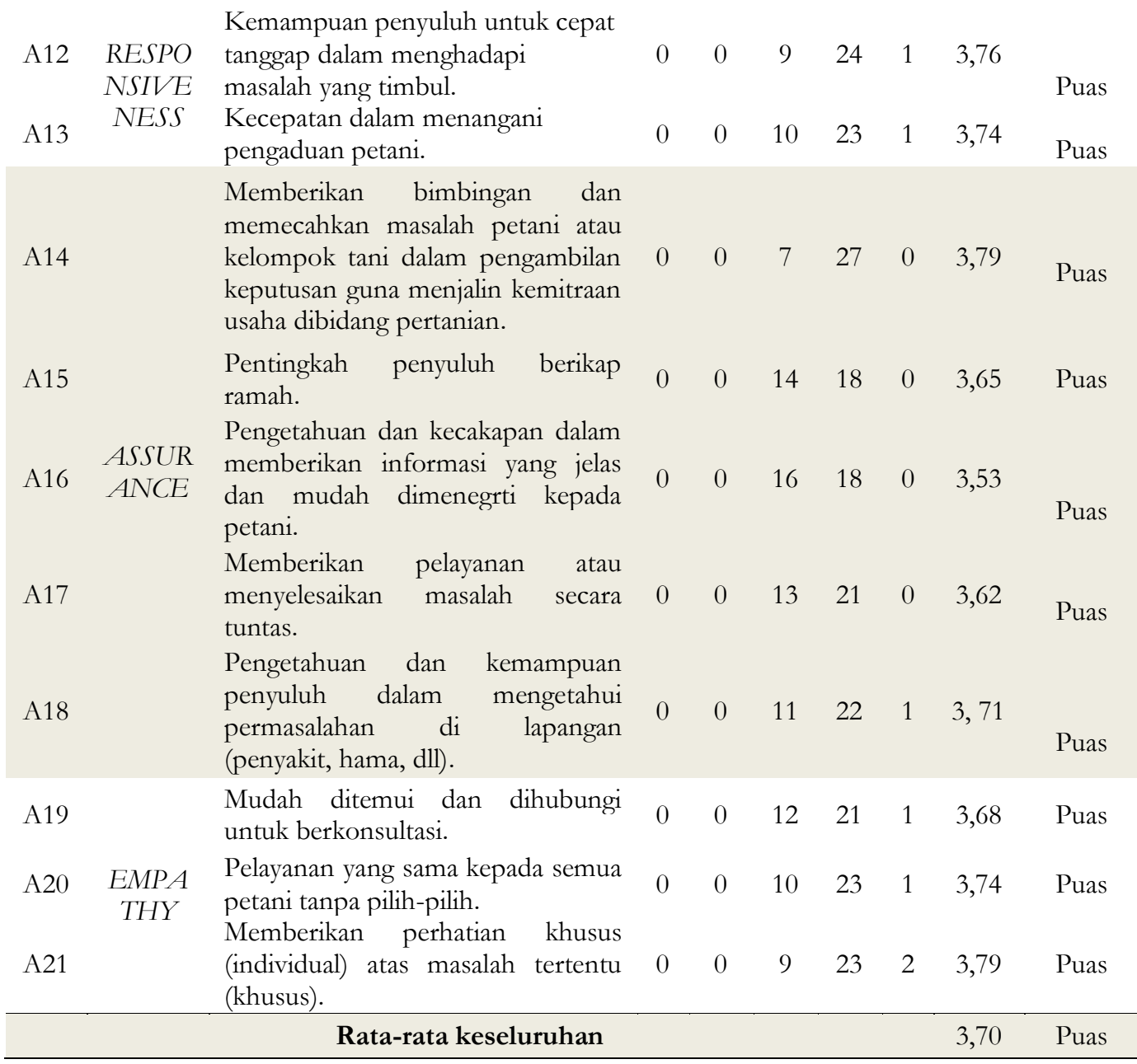

Sumber : Data Primer (diolah), 2019.

Hasil penilaian dari keseluruhan petani yang telah menjawab pertanyaan tingkat kinerja yang tercantum dalam kuesioner diperoleh rata - rata keseluruhan pada setiap pernyataannya dimana nilai tertinggi 3,90 yaitu baikya seorang penyuluh dalam penampilannya atau kerapihannya ini berada pada variabel tangible. Untuk nilai rata-rata terendah dengan nilai 3,38 yang dirasa cukup baik oleh petani dengan pernyataan pentingnya penyuluh lapangan dalam menggunakan bahasa setempat ini juga terletak pada variabel tangible.

Dari penilaian diatas diperoleh rata-rata keseluruhan 3.70 menunjukan bahwa tingkat kinerja berada pada rentang skala $3.40-4.19$ berarti dinilai baik oleh petani.

Dapat disimpulkan dari data penilaian di atas tingkat kepentingan dan tingkat kinerja yang telah diketahui hasilnya, dengan nilai rata - rata tingkat kepentingan sebesar 4,11 dan tingkat kinerja dengan nilai rata - rata 3,70. Dengan nilai rata-rata keseluruhan diatas dapat disimpulkan bahwa petani merasa puas dengan pelayanan atau kinerja penyuluh lapang di Desa Babakan Karet Kecamatan Cianjur Kabupaten Cianjur atas harapan dan kepentingan yang dibutuhkan oleh setiap petani.

\section{Analisis Kuantitatif Importance and Performance (IPA)}

Analisis IPA digunakan untuk mengukur tingkat kepusan konsumen secara menyeluruh terhadap kinerja atribut - atribut penyuluh. Hasil dari pengujian analisis IPA dapat dilihat pada tabel di bawah ini. 
Di bawah ini dapat dilihat tabel yang menunjukan besar rata-rata kepentingan dan kinerja penyuluh lapangan pada setiap atribut yang telah dihitung

Tabel 11. Penilaian Kepentingan Terhadap Penyuluh.

\begin{tabular}{|c|c|c|c|c|c|c|c|c|c|}
\hline No & $\begin{array}{l}\text { VARIA } \\
\text { BEL }\end{array}$ & Pernyataan & 1 & 2 & 3 & 4 & 5 & $\begin{array}{l}\text { rata- } \\
\text { rata }\end{array}$ & $\begin{array}{l}\text { Kriteri } \\
\text { a }\end{array}$ \\
\hline A1 & TANGI & Kerapihan dari penampilan penyuluh. & 0 & 0 & 1 & 24 & 9 & 4,24 & $\begin{array}{l}\text { Sangat } \\
\text { penting }\end{array}$ \\
\hline A2 & BLE & $\begin{array}{l}\text { Kemampuan penyuluh dalam } \\
\text { menggunakan bahasa setempat. }\end{array}$ & 0 & 0 & 6 & 21 & 7 & 4,03 & Penting \\
\hline A3 & & $\begin{array}{l}\text { Praktek langsung di lapangan pada saat } \\
\text { pelatihan dan kunjungan. }\end{array}$ & 0 & 0 & 2 & 26 & 6 & 4,12 & Penting \\
\hline A4 & & $\begin{array}{l}\text { Pentingkah melaksanakan pelatihan } \\
\text { dan kunjungan secara teratur. }\end{array}$ & 0 & 0 & 3 & 25 & 6 & 4,09 & Penting \\
\hline A5 & & $\begin{array}{l}\text { Pengupayaan sarana dan prasarana } \\
\text { yang dibutuhkan petani. }\end{array}$ & 0 & 0 & 3 & 25 & 6 & 4,09 & Penting \\
\hline A6 & & $\begin{array}{l}\text { Pentingkah penyuluh lapang membantu } \\
\text { petani atau kelompok tani dalam } \\
\text { penyusunan rencna kegiatan usaha tani. }\end{array}$ & 0 & 0 & 4 & 25 & 5 & 4,03 & Penting \\
\hline A7 & $\begin{array}{l}\text { RELIA } \\
\text { BILITY }\end{array}$ & $\begin{array}{l}\text { Membantu petani atau kelompok tani } \\
\text { untuk membuat administrasi kelompok } \\
\text { seperti proposal, RDKK, buku } \\
\text { administrasi, laporan bulanan } \\
\text { kelompok dan sebagainya. }\end{array}$ & 0 & 0 & 1 & 28 & 5 & 4,12 & Penting \\
\hline A8 & & $\begin{array}{llr}\text { Pentingkah } & \text { penyuluh } & \text { lapang } \\
\text { menyampaikan } & \text { informasi teknologi } \\
\text { baru. } & & \end{array}$ & 0 & 0 & 1 & 24 & 9 & 4,24 & $\begin{array}{l}\text { Sangat } \\
\text { penting }\end{array}$ \\
\hline A9 & & $\begin{array}{l}\text { Pentingkah penyuluh lapang } \\
\text { menyampaikan informasi pasar. } \\
\text { Pentingkah penvuluh lapang }\end{array}$ & 0 & 0 & 0 & 28 & 6 & 4,18 & Penting \\
\hline A10 & & $\begin{array}{l}\text { menyampaikan informasi peluang } \\
\text { usaha dan permodalan. }\end{array}$ & 0 & 0 & 0 & 29 & 5 & 4,15 & Penting \\
\hline A11 & & $\begin{array}{l}\text { Pengaruh penyuluh lapang terhadap } \\
\text { peningkatan hasil usaha. }\end{array}$ & 0 & 0 & 2 & 30 & 2 & 4,00 & Penting \\
\hline A12 & $\begin{array}{l}\text { RESPO } \\
\text { NSIVE }\end{array}$ & $\begin{array}{l}\text { Kemampuan penyuluh untuk cepat } \\
\text { tanggap dalam menghadapi masalah } \\
\text { yang timbul. }\end{array}$ & 0 & 0 & 2 & 27 & 5 & 4,09 & Penting \\
\hline A13 & NESS & $\begin{array}{l}\text { Kecepatan dalam menangani } \\
\text { pengaduan petani. }\end{array}$ & 0 & 0 & 3 & 26 & 5 & 4,06 & Penting \\
\hline A14 & & $\begin{array}{l}\text { Memberikan bimbingan dan } \\
\text { memecahkan masalah petani atau } \\
\text { kelompok tani dalam pengambilan } \\
\text { keputusan guna menjalin kemitraan } \\
\text { usaha dibidang pertanian. }\end{array}$ & 0 & 0 & 4 & 27 & 3 & 3,97 & Penting \\
\hline A15 & & Pentingkah penyuluh berikap ramah. & 0 & 0 & 3 & 24 & 7 & 4,12 & Penting \\
\hline A16 & $\begin{array}{l}\text { ASSUR } \\
\text { ANCE }\end{array}$ & $\begin{array}{l}\text { Pengetahuan dan kecakapan dalam } \\
\text { memberikan informasi yang jelas dan } \\
\text { mudah dimenegrti kepada petani. }\end{array}$ & 0 & 0 & 1 & 29 & 4 & 4,09 & Penting \\
\hline A17 & & $\begin{array}{l}\text { Memberikan pelayanan atau } \\
\text { menyelesaikan masalah secara tuntas. } \\
\text { Pengetahuan dan kemampuan }\end{array}$ & 0 & 0 & 2 & 26 & 6 & 4,12 & Penting \\
\hline A18 & & $\begin{array}{l}\text { penyuluh dalam mengetahui } \\
\text { permasalahan di lapangan (penyakit, } \\
\text { hama, dll). }\end{array}$ & 0 & 0 & 1 & 25 & 8 & 4,21 & $\begin{array}{l}\text { Sangat } \\
\text { penting }\end{array}$ \\
\hline A19 & $\begin{array}{l}\text { EMPAT } \\
H Y\end{array}$ & $\begin{array}{l}\text { Mudah ditemui dan dihubungi untuk } \\
\text { berkonsultasi. }\end{array}$ & 0 & 0 & 3 & 22 & 9 & 4,18 & Penting \\
\hline
\end{tabular}




\begin{tabular}{llllllllll} 
A20 & $\begin{array}{l}\text { Pelayanan yang sama kepada semua } \\
\text { petani tanpa pilih-pilih. } \\
\text { Memberikan perhatian khusus }\end{array}$ & 0 & 0 & 2 & 25 & 7 & 4,15 & Penting \\
A21 & $\begin{array}{l}\text { (individual) atas masalah tertentu } \\
\text { (khusus). }\end{array}$ & 0 & 0 & 2 & 27 & 5 & 4,09 & Penting \\
\hline \multicolumn{1}{c}{ Rata-rata keseluruhan } & & & & 4,11 & Penting \\
\hline
\end{tabular}

Sumber : Data Primer (diolah), 2019.

Hasil penilaian keseluruhan dari 34 responden yang telah menjawab pertanyaan tentang tingkat kepentingan atas atribut penyuluh yang tercantum dalam kuesioner maka diperoleh rata rata keseluruhan sebesar 4,11.

Tabel 12. Penilaian Kinerja Petani Terhadap Penyuluh.

\begin{tabular}{|c|c|c|c|c|c|c|c|c|c|}
\hline No & $\begin{array}{r}V A R I \\
A B E L\end{array}$ & Pernyataan & 1 & 2 & 3 & 4 & 5 & $\begin{array}{c}\text { rata- } \\
\text { rata }\end{array}$ & $\begin{array}{c}\text { Kriteri } \\
\text { a }\end{array}$ \\
\hline A1 & $T A N G$ & $\begin{array}{l}\text { Kerapihan dari penampilan } \\
\text { penyuluh. }\end{array}$ & 0 & 0 & 8 & 20 & 6 & 3,94 & Puas \\
\hline A2 & IBLE & $\begin{array}{l}\text { Kemampuan penyuluh dalam } \\
\text { menggunakan bahasa setempat. }\end{array}$ & 0 & 2 & 17 & 15 & 0 & 3,38 & $\begin{array}{c}\text { Cukup } \\
\text { puas }\end{array}$ \\
\hline A3 & & $\begin{array}{l}\text { Praktek langsung di lapangan pada } \\
\text { saat pelatihan dan kunjungan. }\end{array}$ & 0 & 0 & 11 & 22 & 1 & 3,71 & Puas \\
\hline A4 & & $\begin{array}{l}\text { Pentingkah melaksanakan pelatihan } \\
\text { dan kunjungan secara teratur. }\end{array}$ & 0 & 0 & 12 & 22 & 0 & 3,65 & Puas \\
\hline A5 & & $\begin{array}{l}\text { Pengupayaan sarana dan prasarana } \\
\text { yang dibutuhkan petani. }\end{array}$ & 0 & 0 & 10 & 24 & 0 & 3,71 & Puas \\
\hline A6 & & $\begin{array}{l}\text { Pentingkah penyuluh lapang } \\
\text { membantu petani atau kelompok tani } \\
\text { dalam penyusunan rencna kegiatan } \\
\text { usaha tani. }\end{array}$ & 0 & 0 & 10 & 22 & 2 & 3,76 & Puas \\
\hline A7 & $\begin{array}{l}\text { RELI } \\
\text { ABILI } \\
\text { TY }\end{array}$ & $\begin{array}{l}\text { Membantu petani atau kelompok tani } \\
\text { untuk membuat administrasi } \\
\text { kelompok seperti proposal, RDKK, } \\
\text { buku administrasi, laporan bulanan } \\
\text { kelompok dan sebagainya. }\end{array}$ & 0 & 0 & 12 & 21 & 1 & 3,68 & Puas \\
\hline A8 & & $\begin{array}{l}\text { Pentingkah penyuluh lapang } \\
\text { menyampaikan informasi teknologi } \\
\text { baru. }\end{array}$ & 0 & 0 & 11 & 22 & 1 & 3,71 & Puas \\
\hline A9 & & $\begin{array}{l}\text { Pentingkah penyuluh lapang } \\
\text { menyampaikan informasi pasar. }\end{array}$ & 0 & 0 & 6 & 27 & 1 & 3,85 & Puas \\
\hline A10 & & $\begin{array}{l}\text { Pentingkah penyuluh lapang } \\
\text { menyampaikan informasi peluang } \\
\text { usaha dan permodalan. }\end{array}$ & 0 & 0 & 8 & 26 & 0 & 3,76 & Puas \\
\hline A11 & & $\begin{array}{l}\text { Pengaruh penyuluh lapang terhadap } \\
\text { peningkatan hasil usaha. }\end{array}$ & 0 & 0 & 13 & 21 & 0 & 3,62 & Puas \\
\hline A12 & RESP & $\begin{array}{l}\text { Kemampuan penyuluh untuk cepat } \\
\text { tanggap dalam menghadapi masalah } \\
\text { yang timbul. }\end{array}$ & 0 & 0 & 9 & 24 & 1 & 3,76 & Puas \\
\hline A13 & $\begin{array}{l}V E N \\
\text { ESS }\end{array}$ & $\begin{array}{l}\text { Kecepatan dalam menangani } \\
\text { pengaduan petani. }\end{array}$ & 0 & 0 & 10 & 23 & 1 & 3,74 & Puas \\
\hline A14 & $\begin{array}{l}A S S U \\
R A N C \\
E\end{array}$ & $\begin{array}{l}\text { Memberikan bimbingan dan } \\
\text { memecahkan masalah petani atau } \\
\text { kelompok tani dalam pengambilan } \\
\text { keputusan guna menjalin kemitraan } \\
\text { usaha dibidang pertanian. }\end{array}$ & 0 & 0 & 7 & 27 & 0 & 3,79 & Puas \\
\hline A15 & & Pentingkah penyuluh berikap ramah & 0 & 0 & 14 & 18 & 0 & 3,65 & Puas \\
\hline
\end{tabular}

\begin{tabular}{|c|c|}
\hline KEPUASAN & ASEP SAEPUL ALAM dan MUGI VELAYATI \\
\hline PANDANWANGI & \\
\hline PENYULUH & \\
\hline BABAKANKARET KECAMATAN CIANJUR & \\
\hline
\end{tabular}




\begin{tabular}{|c|c|c|c|c|c|c|c|c|c|}
\hline A16 & & $\begin{array}{l}\text { Pengetahuan dan kecakapan dalam } \\
\text { memberikan informasi yang jelas dan } \\
\text { mudah dimenegrti kepada petani }\end{array}$ & 0 & 0 & 16 & 18 & 0 & 3,53 & Puas \\
\hline A17 & & $\begin{array}{l}\text { Memberikan pelayanan atau } \\
\text { menyelesaikan masalah secara tuntas }\end{array}$ & 0 & 0 & 13 & 21 & 0 & 3,62 & Puas \\
\hline A18 & & $\begin{array}{l}\text { Pengetahuan dan kemampuan } \\
\text { penyuluh dalam mengetahui } \\
\text { permasalahan di lapangan (penyakit, } \\
\text { hama, dll) }\end{array}$ & 0 & 0 & 11 & 22 & 1 & 3,71 & Puas \\
\hline A19 & & $\begin{array}{l}\text { Mudah ditemui dan dihubungi untuk } \\
\text { berkonsultasi }\end{array}$ & 0 & 0 & 12 & 21 & 1 & 3,68 & Puas \\
\hline A20 & $\begin{array}{c}E M P A \\
T H Y\end{array}$ & $\begin{array}{l}\text { Pelayanan yang sama kepada semua } \\
\text { petani tanpa pilih-pilih }\end{array}$ & 0 & 0 & 10 & 23 & 1 & 3,74 & Puas \\
\hline A21 & & $\begin{array}{l}\text { Memberikan perhatian khusus } \\
\text { (individual) atas masalah tertentu } \\
\text { (khusus) }\end{array}$ & 0 & 0 & 9 & 23 & 2 & 3,79 & Puas \\
\hline \multicolumn{8}{|c|}{ Rata-rata keseluruhan } & 3,70 & Puas \\
\hline
\end{tabular}

Sumber: Data Primer (diolah), 2019.

Hasil penilaian dari keseluruhan petani yang telah menjawab pertanyaan tingkat kinerja yang tercantum dalam kuesioner diperoleh rata - rata keseluruhan sebesar 3,70. Analisis IPA ini digunakan untuk mengukur tingkat kepuasan konsumen secara menyeluruuh terhadap kinerja atribut-atribut penyuluh lapangan, dan hasilnya dapat dilihat pada gambar di bawah ini.

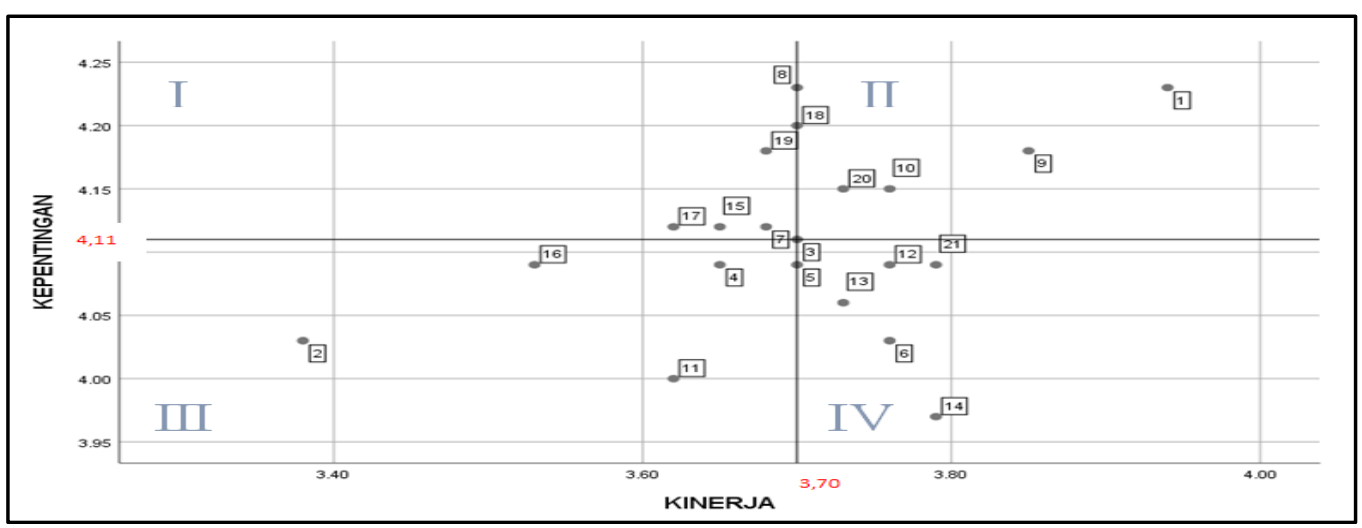

Gambar 7. Diagram Kartesius IPA Peran Penyuluh.

Dari gambar 7. dapat dilihat beberapa lingkaran kecil yang memiliki posisi tersebar, hal itu menandakan atribut - atribut penyuluh dari atribut 1 - 21 yang terbagi dalam 4 (plot) atau bagian - bagian tersebut disebut kuadran dan memiliki arti dan perlakuan yang harus dilakukan berbeda antar kuadran atau tiap kuadran. Rata-rata keseluruhan dari tingkat kepuasan petani yaitu 3,70 maka garis vertikal yang berada pada gambar diatas berada pada angka 3,70 dan untuk garis horizontal menunjukan nilai rata-rata keseluruhan dari tingkat kepentingan suatu objek atau atribut-atribut pelayanan yang telah diberikan kepada petani berupa kuisioner dengan nilai keseluruhan ratarata 4,11 .

\section{Kuadran 1 Prioritas Utama}

Atribut - atribut yang berbeda pada kuadran ini dianggap sangat penting oleh petani tetapi pelayanan kurang memuaskan. Beberapa atribut seperti yang ada pada kuadran 1

Dapat dilihat pada kuadran 1 pada gambar diatas petani merasakan atribut pelayanan yang dianggap penting namun pada kenyataannya atribut-atribut tersebut belum sesuai dengan harapan petani 
sehingga petani belum merasa puas dengan apa yang diberikan oleh penyuluh lapangan. Atribut yang terletak pada kuadran ini merupakan prioritas utama untuk ditingkatkan oleh penyuluh untuk mendapatkan kepuasan dan kepentingan yang seimbang sesuai dengan harapan petani. Diantaranya terletak pada atributatribut:

No 7 Membantu petani atau kelompok tani untuk mebuat administrasi kelempok seperti proposal, RDKK, buku administrasi, laporan bulanan kelompok dan sebagainya.

No 8 Pentingkah penyuluh lapang dalam menyampaikan informasi baru.

No 15 Pentingkah penyuluh bersikap ramah.

No 17 Memberikan pelayanan atau menyelesaikan secara tuntas.

No 19 Mudah ditemui dan dihubungi untuk konsultasi

\section{Kuadran 2 Pertahankan Kinerja}

Pada kuadran 2 penyuluh lapangan harus dapat mempertahankan atas pelayanan yang sesuai dengan atributatribut kinerja yang diberikan kepada setiap petani. Atribut - atribut kinerja penyuluh seperti :

No 1 Kerapihan dari penampilan penyuluh.

No 9 Penyuluh lapangan menyampaikan informasi peluang usaha dan permodalan..

No 10 Pengaruh penyuluh lapang terhadap peningkatan hasil usaha.

No 18 penyuluh lapang mudah ditemui dan dihubungi untuk konsultasi.

No 20 Pelayanan yang sama kepada semua petani

Atribut - atribut yang terletak pada kuadran ini dianggap sebagai faktor penunjang bagi kepuasan petani. Artinya, jika penyuluh dapat mempertahankan kinerja pada hal - hal yang dianggap penting terhadap pelayanan penyuluh. Sehingga penyuluh berkewajiban dan harus dapat mempertahankan prestasi yang telah dicapai.

\section{Kuadran 3 Prioritas Rendah}

Pada kuadran ini petani tidak mengangap penting dan belum merasakan kepuasan terhadap atribut pelayanan yang diberikan oleh penyuluh lapangan sehingga penyuluh tidak perlu memprioritaskan atau terlalu memberikan perhatian pada atribut tersebut, cukup sekedar mempertahankan dan menyesuaikan dengan kondisi saat ini. Atribut tersebut yaitu :

No 2 Praktek langsung di lapangan pada saat pelatihan dan kunjungan.

No 4 Pengupayaan sarana dan prasarana dan kunjungan secara teratur .

No 11 Membantu petani atau kelompok tani untuk membuat administrasi.

No 16 Pengetahuan dan kecakapan dalam memberikan informasi yang jelas dan mudah dimengerti kepada petani.

\section{Kuadran 4 Cenderung Berlebihan}

Disini petani merasakan atribut yang ada dianggap sudah memuaskan, namun tidak terlalu penting oleh petani sehingga penyuluh tidak perlu terlalu banyak mengalokasikan sumberdaya yang terkait dengan atribut - atribut tersebut, cukup hanya sekedar mempertahannya.

\section{Analysis Customer Satisfation Index (CSI)}

Dari data yang telah diperoleh melalui kuesioner yang telah diberikan dan dijawab oleh setiap petani maka tahap selanjutnya dilakukan analisis CSI. Metode CSI digunakan untuk menganalisis sejauh mana tingkat kepentingan dan tingkat kinerja atribut penyuluh hasilnya dapat dilihat pada tabel 13. sebagai berikut : 
Tabel 13. Perhitungan Custumer Satisfation Index (CSI).

\begin{tabular}{|c|c|c|c|c|c|}
\hline No & Atribut - Atribut Pelayanan & MIS & MSS & WF & WS \\
\hline A1 & Kerapihan dan penampilan penyuluh & 4,23 & 3,94 & 0,049 & 0,193 \\
\hline A 2 & $\begin{array}{l}\text { Kemampuan penyuluh dalam melaksanakan bahasa } \\
\text { setempat }\end{array}$ & 4,03 & 3,38 & 0,047 & 0,158 \\
\hline A3 & Praktek langsung di lapangan & 4,11 & 3,7 & 0,048 & 0,176 \\
\hline A4 & Pelatihan dan kunjungan secara teratur oleh penyuluh & 4,09 & 3,65 & 0,047 & 0,173 \\
\hline A5 & Pengupayanan sarana dan prasarana & 4,09 & 3,7 & 0,047 & 0,175 \\
\hline A6 & Penyusunan rencana kegiatan usaha tani & 4,03 & 3,76 & 0,047 & 0,176 \\
\hline A7 & Membantu administrasi kelompok & 4,12 & 3,68 & 0,048 & 0,176 \\
\hline A8 & Memberikan informasi teknologi baru & 4,23 & 3,7 & 0,049 & 0,181 \\
\hline A9 & Memberikan informasi pasar & 4,18 & 3,85 & 0,048 & 0,186 \\
\hline A10 & Memberikan informasi peluang usaha dan permodalan & 4,15 & 3,76 & 0,048 & 0,181 \\
\hline A11 & Peningkatan hasil usaha & 4 & 3,62 & 0,046 & 0,168 \\
\hline A12 & Cepat tanggap dalam menghadapi masalah yang timbul & 4,09 & 3,76 & 0,047 & 0,178 \\
\hline A13 & Kecepatan menangani pengaduan petani & 4,06 & 3,73 & 0,047 & 0,175 \\
\hline A14 & $\begin{array}{l}\text { Membantu dalam pengambilan keputusan guna } \\
\text { menjalin kemitraan usaha }\end{array}$ & 3,97 & 3,79 & 0,046 & 0,174 \\
\hline A15 & Keramahan & 4,12 & 3,65 & 0,048 & 0,174 \\
\hline A16 & Pengetahuan dan kecakapan dalam memberikan materi & 4,09 & 3,53 & 0,047 & 0,167 \\
\hline A17 & Pelayanan / menyelesaikan masalah secara tuntas & 4,12 & 3,62 & 0,048 & 0,173 \\
\hline A18 & Pengetahuan permasalahan di lapangan & 4,2 & 3,7 & 0,049 & 0,180 \\
\hline A19 & Mudah ditemui atau dihubungi & 4,18 & 3,68 & 0,048 & 0,178 \\
\hline A20 & Pelayanan yang sama kepada petani & 4,15 & 3,73 & 0,048 & 0,179 \\
\hline \multirow[t]{4}{*}{ A21 } & Perhatian khusus atau masalah tertentu & 4,09 & 3,79 & 0,047 & 0,180 \\
\hline & Total & 86,33 & 77,72 & 1 & 3,702 \\
\hline & Weight Average Total (WAT) & 3,70 & & & \\
\hline & Custumer Satisfaction Index (CSI) & $\begin{array}{c}74,03 \\
\%\end{array}$ & & & \\
\hline
\end{tabular}

Sumber: Data Primer (diolah), 2019.

Beradasarkan tabel 13. tentang perhitungan CSI, diperoleh nilai indeks kepuasan petani sebesar 74,03\%. Nilai tersebut berada pada rentang antara 60\% $<C S I \leq 80 \%$ berada pada kategori puas atas atribut - atribut atau peran yang dijalankan dan diberikan oleh penyuluh terhadap petani di Desa Babakankaret Kecamatan Cianjur Kabupaten Cianjur.

\section{KESIMPULAN}

Kesimpulan dari hasil penelitian yang telah disusun dapat dipaparkan dalam pembahasan, terdapat beberapa kesimpulan sebagai berikut :

1. Atribut pelayanan penyuluh lapangan berdasarkan kinerja penyuluh lapangan di Desa Babakankaret Kecamatan Cianjur Kabupaten Cianjur yang dianggap penting oleh petani dan memiliki nilai rata-rata tertinggi pada variabel tangible (A1) dan reliability (A8) dengan perolehan nilai rata-rata $(4,24)$ dan kemudian terletak pada variabel assurance (A18) dengan nilai rataratanya $(4,21)$ dimana ke-3 atribut tersebut memiliki nilai rata-rata yang menunjukan hasil sangat penting. Dan untuk hasil rata-rata terendah terletak pada variable assurance (A14) dengan perolehan nilai rata-rata $(3,97)$.

2. Tingkat kepuasan petani terhadap kinerja penyuluh lapangan di Desa Babakankaret Kecamatan Cianjur Kabupaten Cianjur berdasarkan pengujian diperoleh nilai Costumer Satification Index (CSI) 74,03\% Nilai tersebut ada pada rentang antara 60\% $<$ CSI $\leq 80 \%$ yang menunjukan petani merasa puas atas atribut atau peran yang dilakukan oleh penyuluh lapangan tersebut.

\begin{tabular}{llr}
\hline TINGKAT KEPUASAN PETANI & PADI \\
PANDANWANGI TERHADAP & KINERJA \\
PENYULUH LAPANGAN DI & DESA \\
BABAKANKARET KECAMATAN & CIANJUR \\
KABUPATEN CIANJUR &
\end{tabular}

TINGKAT KEPUASAN PETANI PADI

PENYULUH LAPANGAN DI DESA KABUPATEN CIANJUR 


\section{DAFTAR PUSTAKA}

Bachtiar. 2011. Analisa Faktor-faktor Yang Mempengaruhi Keputusan Mahasiswa Dalam Memilih Politeknik Sawunggalih Aji Purwerejo, Dinamika Sosial Ekonomi.

Berkat dan Sunaryanti. 2015. Analisis Kepuasan Petani Terahadap Kegiatan Penyuluhan Pertanian di Kelurahan Kalampangan Kota Palangkaraya. Jurnal Agribisnis.

D, R. R. 2008. Kepuasaan Pelanggan. Jakarta: PT Gramedia Pustaka Utama.

Departemen Pendidikan Nasional. 2008. Kamus Besar Bahasa Indonesia. Jakarta: PT Gramedia Pusat Utama.

Departemen Pertanian. 2009. Modul Pembekalan Bagi THL-TB Penyuluh Pertanian. Jakarta: Departemen Pertanian Badan Pengembangan Sumber Daya Manusia Pertanian.

Listiawati, Ika. 2010. Analisi Tingkat Kepuasan Petani Terhadap Kinerja Penyuluh Lapang di BP3K Wilayah Ciawi Kabupaten Bogor. Skripsi. Program Sarjana Departemen Penyelngaraan Khusus Departemen Manajemen, Fakultas Ekonomi dan Manajemen.

Naning Wijayanti, DB Paranaon, dan Rita Kalalinggi. 2015. Analisis Tingkat Kepuasan Petani Terhadap Kinerja Penyuluh Pertanian Lapangan (PPL) di Kabupaten Kutai Timur.

Ningsih, Diana. 2017. Persepsi Petani Terhadap Budidaya Padi Pandanwangi di Kelompok Tani Citamiang Kecamatan Gekbrong Kabupaten Cianjur. Skripsi. Prodi Agribisnis. Fakultas Sains Terapan. Universitas Suryakana. Cianjur.

Nurmawan, Fahmi Aprilian. 2010. Analisis Kemitraan Antara Koperasi Mitra Tani Parahyangan dengan Petani Padi Pandanwangi di Kecamatan Gekbrong dan Warungkondang. Skripsi. Program Studi Agribisnis Fakultas Sains Terapan Universitas Suryakancana.
Nuryana, Ayi Qobul. (n.d.). Tingkat Kepuasan Stakeholder Padi Pandanwangi Cianjur Terhadap Keberadaan dan Peran Masyarakat Pelestari Padi Pandanwangi Cianjur (MP3C. Skirpsi. Program Studi Agribisnis Faakultas Sains Terapan Universitas Suryakancana Cianjur.

Renfinasari, Fensi. 2012. Pengaruh Kemampuan Kerja dan Kepuasan Kerja Terhadap Penyuluh Pertanian Lapangan (PPL) di Badan Pelaksanaan Penyuluhan dan Ketahanan Pangan Kabupaten Bangka Selatan. Tesis. Program Pascasarjana Universitas Terbuka Pangkal Pinang.

Ritongga, N. S. 2016. Analisis Tingkat Kepuasan Petani Padi di Desa Pir Trans Sosa IV Terhadap Kinerja Penyuluh Pertanian Pada Balai Penyuluh Kecamatan Hutaraja Tinggi Kabupaten Padang Lawas Provinsi Sumatera Utara .

Saheda, Amatuas. 2008. Preferensi dan Kepuasan Petani Terhadap Benih Padi Varietas Lokal Pandanwangi di Kabupaten Cianjur. Skripsi. Fakultas Pertanian, Institut Pertanian Bogor.

Salim, Abbas. 2007. Assuransi dan Manajemen Risiki. Jakarta: Raja Grafindo Persada.

Subagio, Dini Bayu. 2010. Tingkat Kepuasan Petani Terhadap Kinerja Pelayanan Penyuluh Pertanian Di Desa Situ Udik Kecamatan Cibungbulang Kabupaten Bogor Jawa Barat. Skirpsi. Departemen Agribisnis Fakultas Ekonomi dan Manajemen Institut Pertanian Bogor.

Sugiono. 2008. Metode Penelitian Kuantitatif Kualitatif dan R\&D. Bandung: Alfabeta

Sugiono. 2009. Metode Penelitian Kuantitatif Kualitatif dan R\&D. Bandung: Alfabeta.

Sugiono. 2015. Metode Penelitian Kuantitatif Kualitatif dan R\&D. Bandung: Alfabeta. 